\title{
Towards a Latin American and Caribbean international census of marine microbes (LACar - ICoMM): overview and discussion on some current research directions
}

\author{
L.F. Artigas ${ }^{1 *}$, E. Otero², R. Paranhos ${ }^{3}$, M.L. Gómez ${ }^{4}$, C. Piccini ${ }^{5}$, M. Costagliola ${ }^{6}$, R. Silva ${ }^{6}$, \\ P. Suárez ${ }^{7}$, V.A. Gallardo ${ }^{8}$, D.U. Hernández-Becerril ${ }^{9}$, A. Chistoserdov ${ }^{10}$, R. Vieira ${ }^{11}$, M. Perez- \\ Cenci $^{12}$, J.F. Ternon ${ }^{13}$, B. Beker ${ }^{14}$, M. Thyssen ${ }^{15}$, H. Dionisi ${ }^{16}$, I. do Rosario Marinho-Jaussaud ${ }^{1}$, \\ A. Gonzalez ${ }^{3}$, C. Hurtado ${ }^{4}$, J.P. Parra ${ }^{4}$, C. Alonso ${ }^{5}$, C. Hozbor ${ }^{6}$, S. Peressutti ${ }^{6}$, R. Negri ${ }^{6}$, \\ C. Espinoza ${ }^{8}$, A. Cardoso ${ }^{11}$, O. Martins ${ }^{11}$, F. Covacevich ${ }^{12}$, C. Berón ${ }^{12}$ \& G.L. Salerno ${ }^{12}$ \\ 1. UMR LOG (FRE 2816 ELICO), MREN - Université du Littoral (ULCO), Wimereux, France. Felipe.Artigas@univ- \\ littoral.fr (*corresponding author). \\ 2. Departamento de Ciencias Marinas, Universidad de Puerto Rico, Mayagüez, Puerto Rico. eotero@uprm.edu \\ 3. Laboratorio de Hidrobiologia, Universidade Federal do Rio de Janeiro, Brasil. rodpar@biologia.ufrj.br \\ 4. Instituto de investigaciones Marinas INVEMAR, Santa Marta, Colombia. mlgomez@invemar.org.co \\ 5. Laboratorio de Microbiologia, IIBCE, Universidad de la República, Uruguay. piccini@iibce.edu.uy \\ 6. Laboratorio de Microbiologia Marina, INIDEP, Mar del Plata, Argentina. mcosta@inidep.edu.ar, \\ 7. Universidad Simón Bolivar, Venezuela. pulisuarez@gmail.com \\ 8. Departamento de Oceanografía, Universidad de Concepción, Chile. vagallar@udec.cl \\ 9. Instituto de Ciencias del mar y Limnología, Universidad Nacional Autónoma de México (UNAM), México D.F., \\ México.dhernand@icmyl.unam.mx \\ 10. University of Lousiana, Lafayette, LA ,USA. ayc6160@louisiana.edu \\ 11. Inst. Medical Biochemistry, Universidade Federal do Rio de Janeiro, Brasil. \\ 12. Centro de Investigaciones Biológicas, FIBA, Vieytes 3103, 7600 Mar del Plata, Argentina. mperezcenci@fiba.org.ar \\ 13. UR 053 ELISA - IRD Cayenne, F. Guiana and UR 109 “THETIS”, CRHMT IRD / IFREMER, Sète, France. Jean. \\ Francois.Ternon@ifremer.fr \\ 14. L.S.E.M. (UMR CNRS 6539), IUEM- Plouzané, France. Beatriz.Beker@univ-brest.fr \\ 15. LMGEM, Centre d'Océanologie de Marseille, France. thyssen@com.univ-mrs.fr \\ 16. CENPAT-CONICET, Puerto Madryn, Chubut, Argentina. hdionisi@cenpat.edu.ar
}

Received 13-VII-2007. ～C Corrected 03-I-2008. ～Accepted 13-II-2008.

\begin{abstract}
The International Census of Marine Microbes (ICoMM), together with the South American and Caribbean Steering Committees of the Census of Marine Life program (CoML), supported the initiative of launching a regional ICoMM node (LACar ICoMM). This network aims at promoting discussions among scientists currently involved in marine microbial studies carried out at both the South American and the Caribbean regions, in order to evaluate the research capabilities and to identify complementary strengths and/or possibilities for enhanced collaboration, that would improve the knowledge on marine microbes and their biodiversity in both regions. We present an overview and discussion on some of the directions of current research on marine microbes in these regions. Concerning the marine phytoplankton studies, the best known taxonomic groups are diatoms and dinoflagellates. In Mexican marine waters, the number of taxa recorded to date is of about 1400 . Studies dealing with bacterial, phytoplankton and/or cyanobacterial dynamics are carried out in the Caribbean coastal and oceanic marine systems, underscoring the importance of various environmental states, modulated by geographic and seasonal patterns as well as by the expression of large South American rivers. One of the main issues of this type of survey is the determination of wet and dry seasonal patterns of bacterial dynamics, in seascapes off Puerto Rico, with moderate to absent river inputs. Phytoplankton and bacterioplankton dynamics are also studied in F. Guiana coastal and shelf systems under direct Amazon influence, well known for their important fisheries resources, as well as in other South American marine systems influenced by important fresh water inputs or under upwelling conditions. Bacterial and/or picoeukaryotes diversity are assessed in particular
\end{abstract}


marine systems such as coastal lagoons in Uruguay, the Rio de la Plata estuary and adjacent areas, as well as in sediments of the Oxygen Minimum Zone (OMZ) off South American Pacific coast, and in anoxic waters of the Cariaco Basin. Findings of a diverse range of pico-autotrophs (Patagonian shelf) and particular communities of big filamentous bacteria (OMZ zone off the South American Pacific) represent recent discoveries in those areas. In polluted coastal systems, bacteria with ability to degrade pesticides and hydrocarbons are currently monitored. In coastal areas of the Colombian Caribbean, 64 native marine bacterial strains were isolated from sediment samples. The oil-degrading bacteria are also studied in the Orinoco Delta, submitted to intensive oil exploitation. Furthermore, the Microbial Observatory of Rio de Janeiro (MoRio) established in Guanabara Bay (Brazil), constitutes a model for the study of threatened tropical coastal systems by exploring microbial biodiversity in different coastal systems (including unpolluted sites). The estimation of the activity and diversity of hydrocarbon and oil-degrading bacteria is assessed also in temperate waters and sediments of coastal systems of Argentina. Sharing knowledge and capabilities in common strategies would allow a better understanding of marine microbial diversity patterns in both regions. Rev. Biol. Trop. 56 (Suppl. 1): 183-214. Epub 2008 May 30.

Keywords: Marine microbial biodiversity, phytoplankton and bacterial dynamics, microbial bioremediation, South America and Caribbean Sea.

Microbial communities define the magnitude and pathways of organic matter, nutrient and energy dynamics in aquatic systems. Although microbial metabolism and productivity are at present being described in many marine ecosystems, only scarce information on microbial dynamics and community composition is available for the planktonic and benthic realms of many coastal and oceanic regions. Such information is important to fully understand topics such as biogeochemical processes and gradients in coastal and open ocean waters, in sandy, muddy and calcareous sediments; to better evaluate the impact of pollution and/or global climate change; to evaluate and prevent coral diseases, to study microepibiotic relationships and to assess the importance of endosymbionts in the production of pharmacologically important compounds. This information gap is reflected in the limited availability of microbial diversity assessments from marine systems in the Caribbean and South American region.

In the framework of the Census of Marine Life, both South American and Caribbean Steering Committees (NRICs) are working to improve our knowledge of marine biodiversity. Since 2006, the International Census of Marine Microbes, the CoML-S.A. and the CaribbeanCoML supported the initiative of launching a regional ICoMM node (LACar ICoMM) in order to promote discussions among scientists currently involved in marine microbial studies in Latin America and the wider Caribbean, to evaluate the research capabilities and to identify complementary strengths and/or possibilities for enhanced collaboration, that would improve the knowledge on marine microbes and their biodiversity, encompassing both the Archaea, Bacteria and Eukarya domains. This network aims at catalyzing the sharing of knowledge, experience, sampling facilities and methodologies of the different research laboratories involved in these studies, to promote the development of joint cross systems projects.

Bacteria, Archaea and Eukaryotic protists dynamics in coastal and oceanic systems underscores the importance of various environmental states modulated by geographic and seasonal patterns, as the influence of large South American river plumes on both South American and the Caribbean Basin productivity, the importance of littoral gradients, the impact of human activities and the bioremediation by natural or induced processes, the enhanced productivity of upwelling systems, the metabolism of oxic/anoxic systems, etc.

We propose here to give an overview and discussion on some of the directions of current research on marine microbes in both regions, by presenting and discussing some already published studies and also by showing original data on different marine systems that represent part of the ecological diversity of both regions. 
One of the main issues of the past and ongoing surveys is the determination of phytoplankton diversity, as it is the case for marine waters of the Mexican Pacific, Gulf of Mexico and Mexican Caribbean areas (HernándezBecerril 2003), carried out mainly by microscopic observations. On the other hand, despite the large amount of studies on the distribution, function and diversity of microorganisms related to estuarine and coastal oceanic ecosystems, the knowledge of the microbial ecology and diversity of the mixohaline zones and adjacent marine waters is rather poor, particularly on basic aspects related to picoplankton distribution, dynamics, and regulating processes. Moreover, within coastal systems, coastal lagoons are highly vulnerable to human activities, and consequently, are experiencing some of the most rapid degradation and loss (Costanza et al. 1993, Kjerve 1994).

The seasonal patterns of bacterial and cyanobacterial dynamics (abundance and productivity) are currently assessed, as in seascapes with moderate to absent river inputs, including coral reef waters, as in marine systems off Puerto Rico (Otero 2001, Otero et al. unpubl.). Combined bacterial and phytoplankton dynamics are also studied in F. Guiana coastal and shelf systems, known for their important fisheries resources, under important direct (local rivers, important littoral mud banks) or remote (Amazon River) continental influence (Artigas \& Guiral 2002, Artigas et al. 2005, Artigas et al. unpubl.). More particularly, the enormous fluidized mud deposits that occur along thousands of kilometers of the Guianas tropical continental margin downdrift of the Amazon River, are being characterized for their microbial diversity and metabolisms (Madrid et al. 2001; Chistoserdov et al. unpubl.). In littoral subtropical lagoons, showing important gradients, the characterization of bacterial diversity patterns is in process by means of molecular determination, as it is the case in the marine littoral area (coastal lagoons) of Uruguay (Piccini et al. 2006; Alonso et al. unpubl.). Adjacent waters of a strong and wide salinity gradient (Rio de la Plata and
Argentinian shelf) are currently sampled in order to study the general diversity of picoplankton by comparing polluted an unpolluted systems (Costagliola et al. unpubl.). Particular bacterial communities are being characterized in Oxygen Minimum Zones (OMZ) off Chile, Perú, Ecuador, Panamá and Costa Rica (big filamentous bacteria, Gallardo and Espinoza 2007), whereas bacterial diversity is explored in the second largest and only truly marine anoxic basin in the world, the Cariaco Basin (Venezuela, Chistoserdov et al. unpubl.).

If estuaries, littoral and coastal areas present strong chemical and biological gradients, in urbanized areas, industrial and domestic pollution is added by human interference. Research in microbial diversity and community dynamics is carried out in order to better understand polycyclic aromatic hydrocarbon biodegradation processes in threatened intertidal sediments, as it is the case in coastal and shelf systems off the Orinoco River in Venezuela, the coastal areas of the Colombian Caribbean and the Argentinian Patagonia (Dionisi et al. submitted). Bacterial biodiversity and metabolisms are assessed in the Microbial Observatory established in the Guanabara Bay (Rio de Janeiro, Brazil), that constitutes a eutrophic estuarine system located in a humid tropical region surrounded by the second largest metropolitan area in Brazil (Vieira et al. 2007 a, b).

After presenting the main results concerning some of these different marine systems, the discussion section will focus on the main issues and questions still unsolved, on reviewing some already published studies, and on the possibility of combining efforts, methodologies and strategies that could enhance our knowledge of the ecology and diversity of marine microbes in the wide range of marine coastal and ocean systems of both regions.

\section{MATERIALS AND METHODS}

Sampling sites: Table 1 summarizes the type of data presented in this review, the sampling locations, the methodology employed, as well as the status of the data. 
TABLE 1

Overview of the different studies presented and discussed in the text

Type of data

Phytoplankton taxonomy

Bacterial and cyanobacterial dynamics

Bacterial and phytoplankton dynamics

Bacterial diversity

Bacterial diversity \& dynamics

\section{Cyanobacterial diversity, bacterial abundance}

Bacterial diversity

Bacterial diversity

Bacterial diversity and specific activities

Bacterial diversity and specific activities

Bacterial diversity and specific activities

Bacterial and Archaeal diversity and activities
Sampling locations

Mexican Pacific, Gulf of Mexico, Caribbean waters

Puerto Rican coastal and shelf waters

French Guiana estuarine, coastal and shelf waters (Amazon plume)

French Guiana fluid muds

Uruguayan coastal lagoon waters

Argentinian shelf waters

Oxygen Minimum Zone sediments, off Chile

Anoxic waters of the CARIACO Basin, Venezuela

Argentinian Rio de la Plata estuarine and shelf waters

Orinoco plume coastal and shelf sediments

Colombian Caribbean
coastal sediments

Guanabara Bay and adjacent waters and sediments, Rio de Janeiro, Brazil
Methodology employed

Inverted microscopic

determinations, scanning electron microscope (SEM), molecular tools

Microsopic epifluorescence counts, ${ }^{3} \mathrm{H}$-Leucine incubations

Inverted and epifluorescence microscope determinations, SEM, flow cytometry, ${ }^{3} \mathrm{H}$-Thymidine incubations

Microbial isolates. Microbial specific activities (incubations). Molecular tools : DNA extraction, PCR amplification

Microscopic epifluorescence counts, enrichment experiments, bacterial activities (incubations), FISH, CARD-FISH

Microsopic epifluorescence counts, molecular tools : DNA extraction, PCR amplification on cyanobacteria, DGGE

Phase contrast microscopic observations

Molecular tools : DNA extraction, PCR amplification

Box-A fingerprint patterns, phylogenetic affiliation of LASdegrading strains

Cultures and incubations of oil degrading bacterial strains

Cultures and incubations of Diesel fuel and Aldrin degrading bacterial strains

DNA extraction, PCR amplification on collected free and attached Bacteria and Archaea

\section{Status (published or} unpublished data)

Hernández-Becerril (2003), HernándezBecerril and BravoSierra (2004), Okolodkov (2005), Band-Schmidt et al. (2004)

Otero, 2001; Otero et al. (unpublished)

Artigas and Guiral (2002); Ternon et al. (2005) Artigas et al. (2005; 2007; unpublished)

Madrid et al. (2001); Chistoserdov et al. (unpublished)

Piccini et al. (2006); Alonso et al. (unpublished)

Diez et al. (2001), Covacevich et al. (2006); Silva et al. (unpublished)

Gallardo and Espinoza (2007)

Chistoserdov et al. (unpublished)

Costagliola et al.

(unpublished)

Suarez et al.

(unpublished)

Marín et al. (2004) ;

Gomez et al. (2006; unpublished)

Vieira et al. (2007a, b) 
Water samples for phytoplankton analysis were taken from many areas of the Mexican Pacific, Gulf of Mexico and Caribbean waters, of different oceanographic and trophic conditions, more or less subjected to anthropogenic influence. We present and discuss some already published data.

The insular shelf of southwestern Puerto Rico encompasses a complex seascape integrated by coastal lagoons, mangroves, bays, coral reefs, seagrasses, deep reefs, muddy and bare sand underwater plains. On the other hand, the Bay of Mayagüez is under the influence of three major rivers of Puerto Rico. The oceanic realm to the South completes the complexity of this northern Caribbean region. Samples for cyanobacterial and heterotrophic bacterial abundance and production were taken in September 2001 (wet season) and February 2002 (dry season) in two sites, in the Bay of Mayagüez and in La Parguera (SW of Puerto Rico, Fig. 1). Samples were also collected from surface and down to $200 \mathrm{~m}$ at the Caribbean
Time Series (CaTS; http://www.cats-uprm.org; $\left.17^{\circ} 36^{\prime} ; 67^{\circ} 00^{\prime} \mathrm{W}\right)$ station. We present and discuss here some unpublished results.

From 2000 to 2004, estuarine and coastal waters were sampled at different seasons (wet and dry seasons) in central French Guiana, with transects from Approuague, Kaw and Mahury estuaries (Artigas \& Guiral 2002, "ELISA Estuaries", Fig. 2) to the inner shelf (20m depth, "ELISA Coastal", Fig. 2). The influence of the Amazon waters over the F. Guiana shelf was investigated during a cruise ("CHICO-1") in October 2003 (Ternon et al. 2005, Artigas et al. 2005, Baklouti et al. 2007), corresponding to the retroflexion period of the North Brazil Current (NBC). Phytoplankton diversity, phytoplankton and bacterioplankton biomass and productivity, were assessed in surface waters of these different systems. On the other hand, sediment samples were collected off the Sinnamary - Iracoubo rivers, off the Central Coast of F. Guiana, for the study of specific microbial metabolisms and diversity.

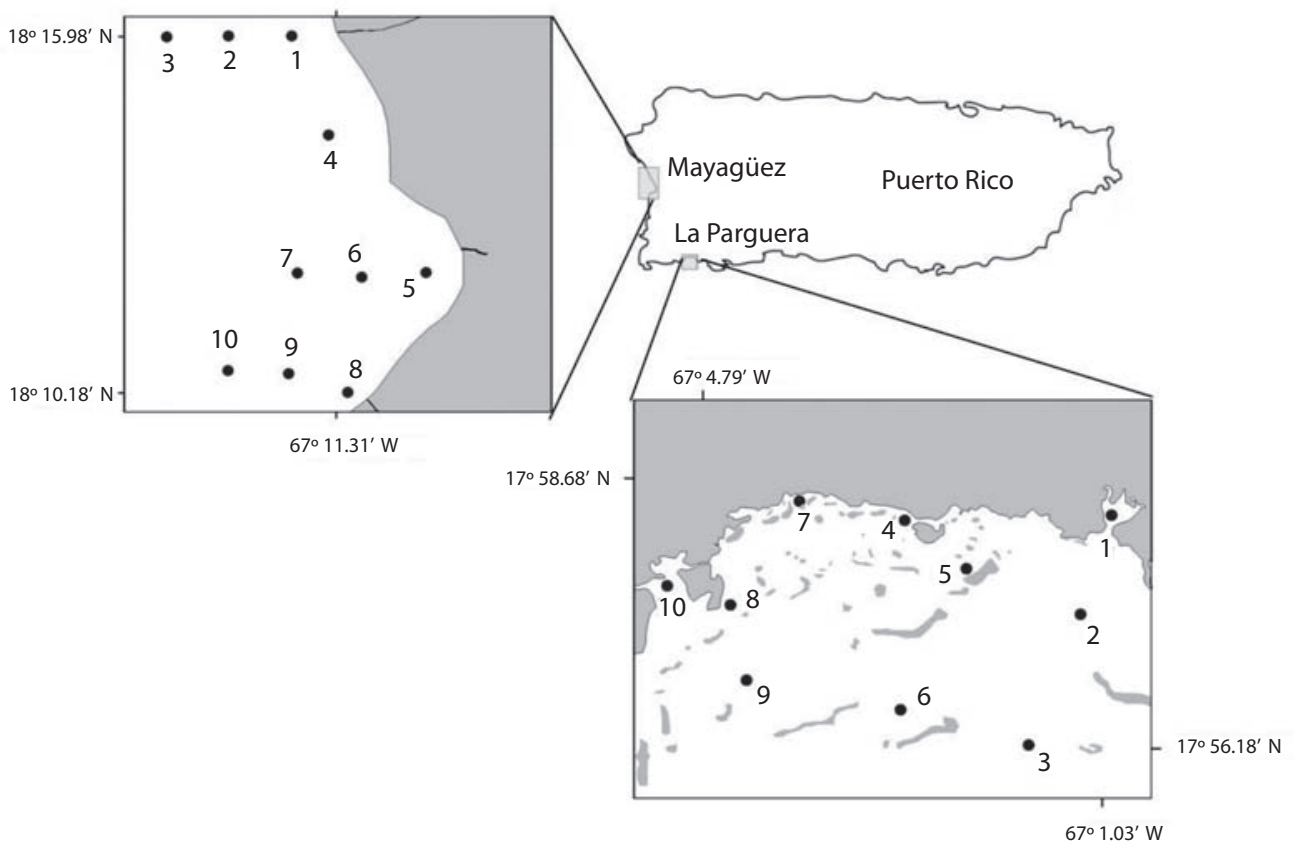

Fig. 1. Location of the sampling stations in the northern Caribbean Sea, in coastal Puerto Rico, in Mayagüez (A) and La Parguera (B) sites. The Caribbean Time Series station is Locate 23 nautical miles south off La Parguera (1700’ N; $\left.17^{\circ} 36^{\prime} \mathrm{W}\right)$. 


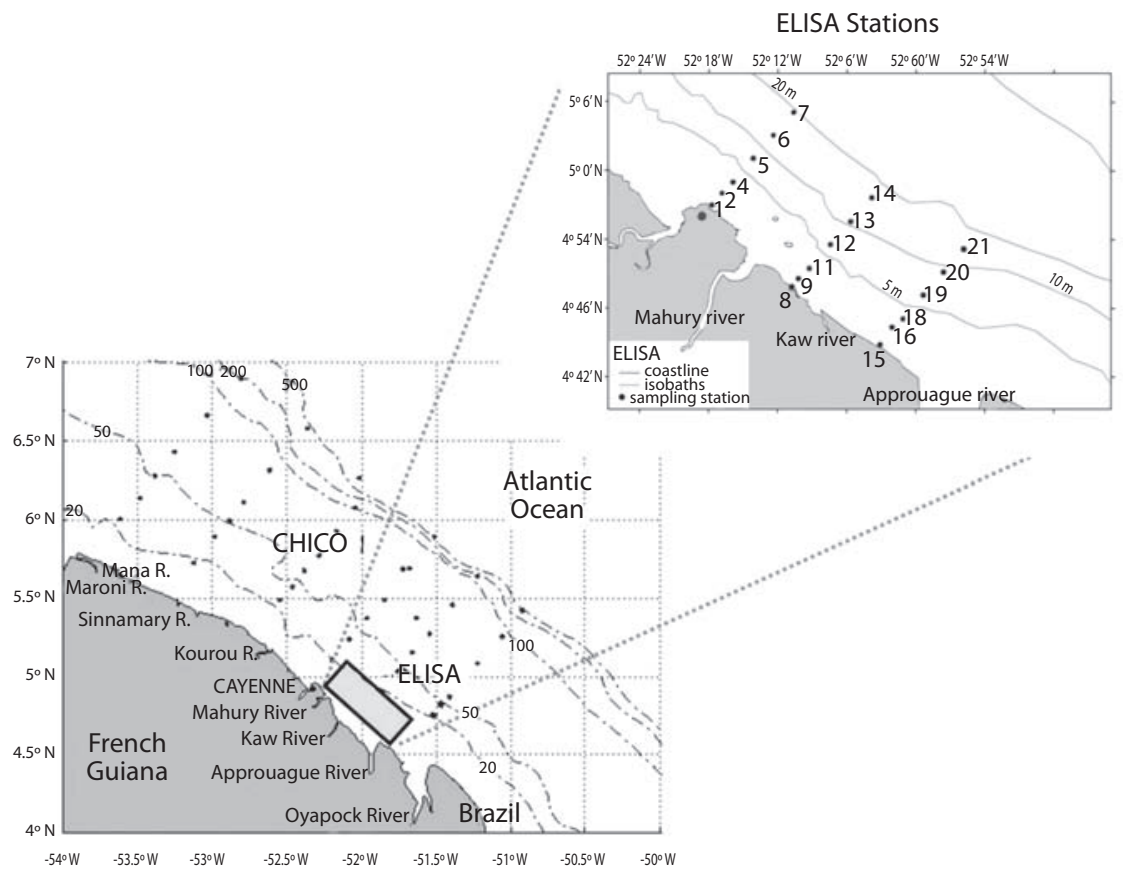

Fig. 2. Sampling areas in estuarine (Mahury - M, Kaw - K \& Approuague - A, "ELISA Estuaries”), coastal ("ELISA Coastal”, see detailed figure with stations) and shelf waters (CHICO-1 cruise), French Guiana (2001-2004).

We present and discuss here some published and unpublished results.

Laguna de Rocha and Laguna Castillos are two Uruguayan subtropical coastal lagoons, which differ in the way they connect to the ocean and in the different influences that they receive from the catchments. Laguna de Rocha (343' S, 54²2' W; Fig. 3a) is a choked highly productive shallow coastal lagoon (mean depth $=0.6 \mathrm{~m}$, area $=72 \mathrm{~km}^{2}$ ) influenced by freshwater and by occasional marine intrusions that gradually divides the lagoon into a zone of brackish water and a freshwater zone that is characterized by high turbidity, high dissolved organic Carbon (DOC) concentration and nutrient concentrations (Conde et al. 2000). The

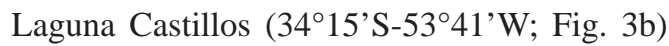
is the largest of the choked coastal lagoons of Uruguay (mean depth $=1.3 \mathrm{~m}$, area $=$ ca. $90 \mathrm{~km} 2$ ) and due to its pristine condition is included in a Ramsar site as well in a $\mathrm{MaB}$ Biosphere Reserve. It is a brackish system (conductivity range from 0.5 to $23 \mathrm{mS} \mathrm{cm}-1$ ) that connects with the Atlantic Ocean through a $10 \mathrm{~km}$ stream (Fig. 3b). Typically, Chafalote is a low turbid but highly humic lateral windprotected compartment of the system, largely dependent on the contribution of dissolved organic matter (DOM) from littoral marshes of submerged and emergent macrophytes (Jorcin 1999). On the contrary, the shallow main body of the lagoon is highly exposed to south-eastern winds, therefore the suspended material contributes to outline a very turbid environment. We present published and unpublished data on bacterial diversity and dynamics in both lagoon systems.

The Río de la Plata is a coastal plain, microtidal estuary $250 \mathrm{~km}$ long and $230 \mathrm{~km}$ wide at the mouth (Fig. 4), characterized by flows with opposing patterns of seasonal variability. Resulting inflow (annual average ca. $22.000 \mathrm{~m}^{3} \mathrm{~s}^{-1}$ ) has moderated maximum and minimum in March-June (late summer-early 

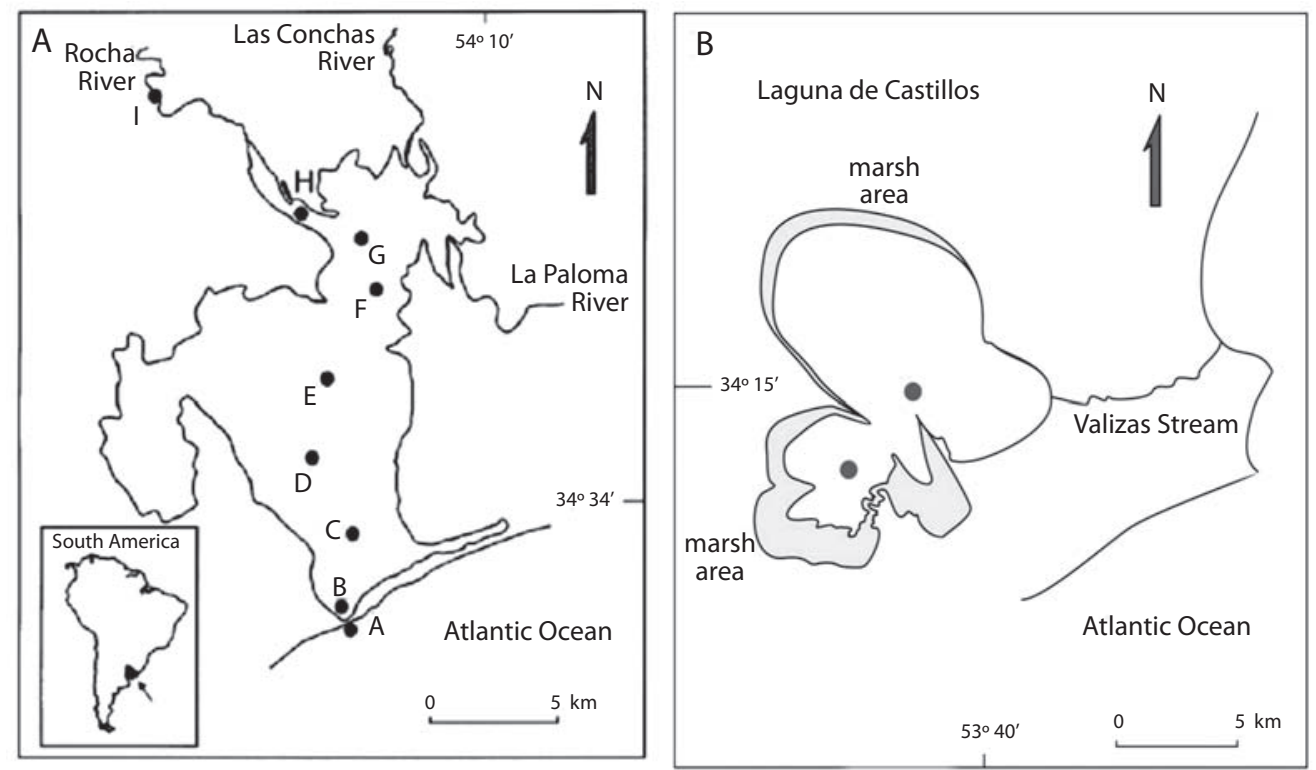

Fig. 3. Laguna de Rocha (A) and Laguna Castillos (B), Uruguay. Sampling sites are indicated by black dots.

winter) and January (summer), respectively. Important variability can occur at larger time scales (i.e. inter annual) associated to ENSO events which induce floods (warm phase) or droughts (cold phase). Water samples were collected in mixohaline and adjacent marine waters of the Rio de la Plata system ( $34^{\circ}-36^{\circ} 30^{\prime}$ S, 55 $5^{\circ}-58^{\circ} 30^{\prime} \mathrm{W}$ ) (Fig. 4), as well as in different areas of the Argentinian continental shelf. On the other hand, a regular monthly sampling was conducted in the Estación Permanente de Estudios Ambientales (EPEA, 38 28's $57^{\circ} 41^{\prime} \mathrm{W}$, Fig. 4) during 12 cruises between September 2003 and August 2004. Water samples were also taken in the Patagonian Shelf during the "GEF-Patagonia 1" cruises (October 2005) at four seasons, off the Península Valdés (Fig. 4). We present here some published and unpublished data on picoplankton (bacterial, cyanobacterial and pico Eukaryotes) from the Argentinian shelf and Rio de la Plata as well as a characterization of bacterial communities showing ability to degrade hydrocarbons.

In the Eastern Southern Pacific Ocean (ESP), the Humboldt Current Ecosystem is studied at different locations, one of these being the Bay of Concepción (Chile, Fig. 5) timeseries station 18 (88 $\mathrm{m}$ depth). The microbial diversity of extensive hypoxic and anoxic sediments is assessed, under the Oxygen Minimum Zone (OMZ, Helly and Levin 2004, Gallardo and Espinoza 2007). The oceanographic setting of the area currently studied comprises two components, 1) the near shore, semi-enclosed Bay of Concepción, and, 2) the offshore, openocean sublittoral environment. Whereas the former receives some anthropogenic impacts (fisheries and municipal outfalls), the latter is affected by remote forcing. Analogous sampling was also carried out at different locations in the coastal Pacific of South and Central America (Chile, Peru, Ecuador, Panama and Costa Rica; Gallardo and Espinoza 2007). We present some results already published of recent discoveries of specific communities of macro- and mega-bacteria in those areas.

A time series study of carbon cycling, phytoplankton and bacterial dynamics is ongoing in a large Venezuelan anoxic basin through the CARIACO (Carbon Retention In A Colored Ocean) program, $10.5^{\circ} \mathrm{N}, 64.67^{\circ} \mathrm{W}$. An additional study on oil degrading bacteria was carried 


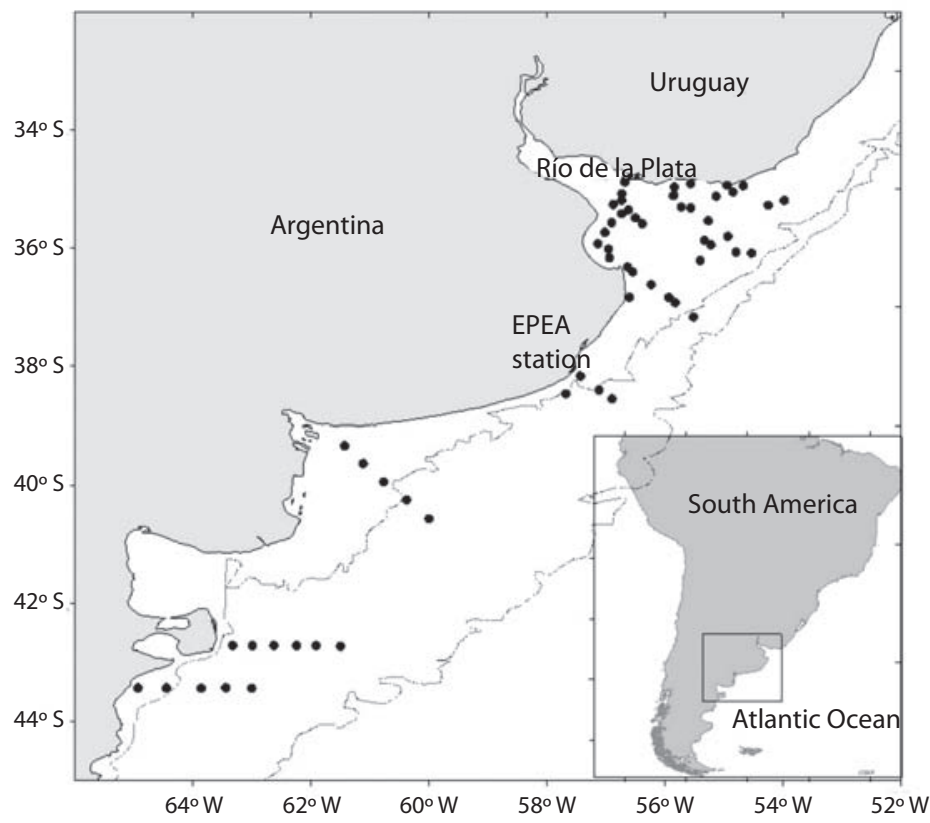

Fig. 4. Sampling sites at mixohaline and adjacent marine waters of the Río de la Plata estuary and the Argentinian shelf.

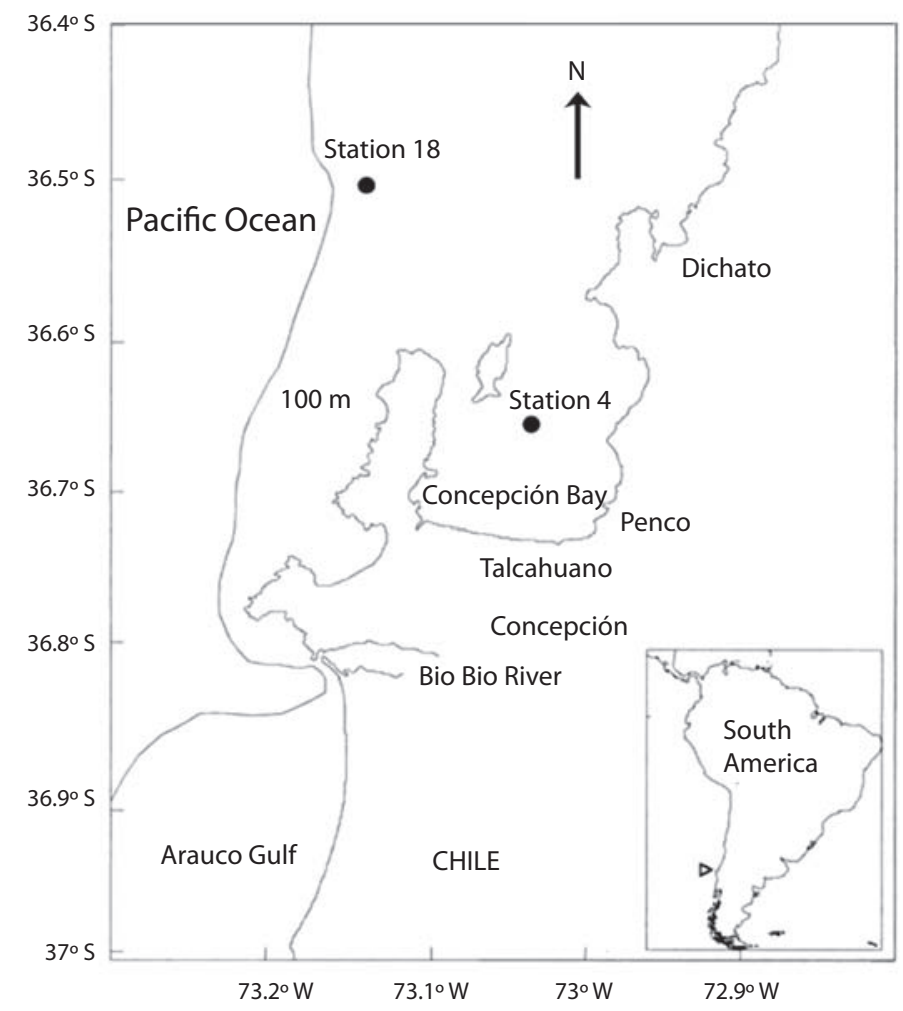

Fig. 5. Sampling stations at Concepción Bay (Central Chile). 


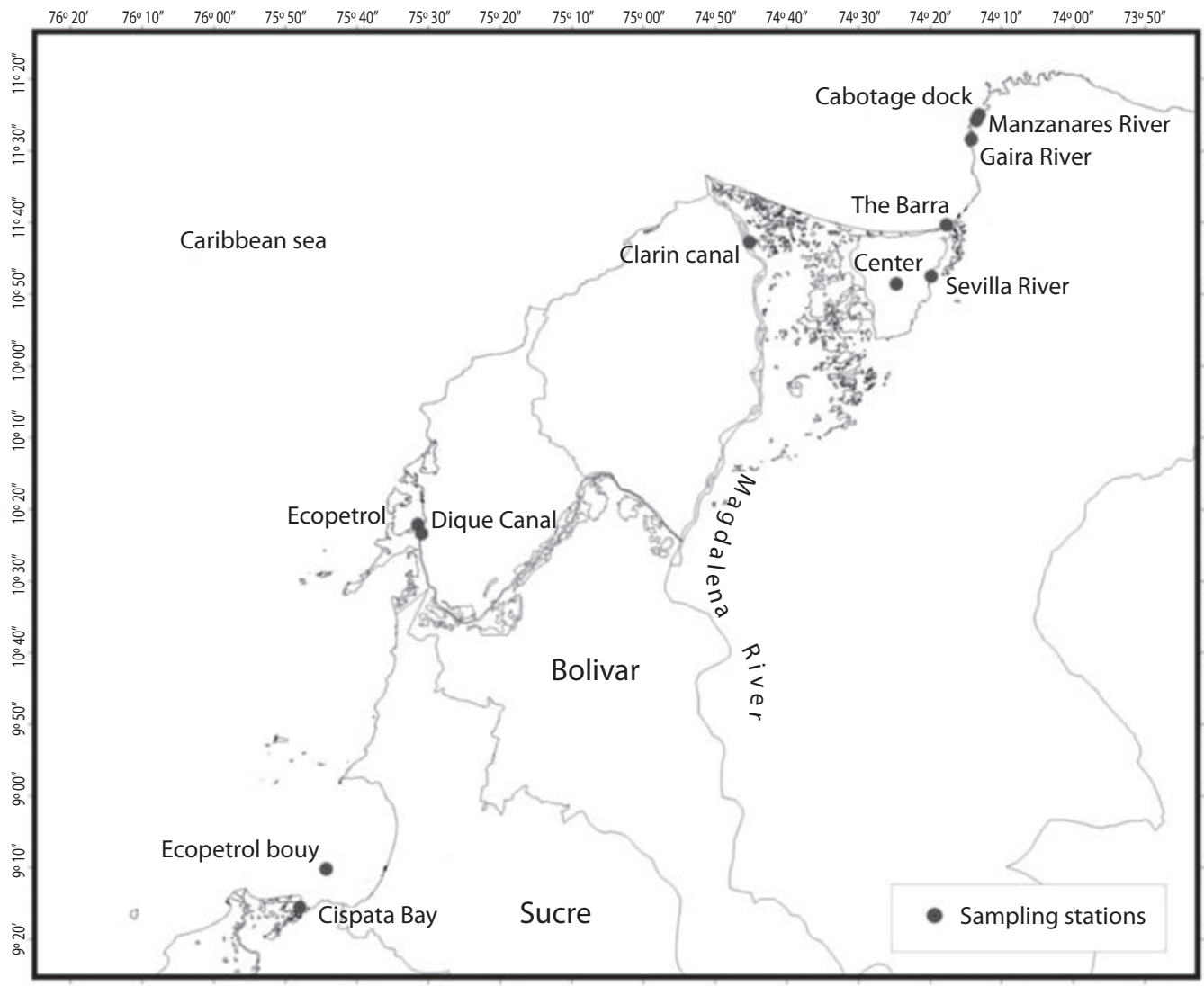

Fig. 6. Sampling stations in the Colombian Caribbean Sea.

out in coastal and shelf waters off the Orinoco River delta in 2001 and 2002, onboard the R.V. ARBV "Punta Brava" (BO-11, Venezuelan Army), as part of an integrated study for the exploration and exploitation of oil by the Venezuelan Company PDVSA-INTEVEP. Water samples were taken in a coastal station off the Orinoco River delta $\left(09^{\circ} 48,2^{\prime} \mathrm{N}\right.$ $\left.60^{\circ} 12,0^{\prime} \mathrm{W}\right)$. Sediments were also sampled by $\sim 1100 \mathrm{~m}$ depth in the Venezuelan Atlantic $\left(09^{\circ} 55,9^{\prime} \mathrm{N} 59^{\circ} 25,7^{\prime} \mathrm{W}\right)$. We present some published and unpublished results on bacterial diversity and potential degrading activities in threatened systems.

Marine and estuarine (Magdalena river) sediment samples were collected in twelve stations (Fig. 6) of Colombian Caribbean contaminated areas (Marín et al. 2004), between
2003 and 2005, for isolating bacteria with ability to degrade oil and pesticides. Four stations were sampled in the Ciénaga Grande of Santa Marta (CGSM), the most important deltaiclagoon system in Colombia and the widest in the Caribbean (Fig. 2b). In each station $500 \mathrm{~g}$ of sediment were collected at $15 \mathrm{~cm}$ depth.

The Guanabara Bay (Rio de Janeiro, Brazil, Fig. 7) is an extremely dynamic ecosystem located at the interface between freshwater and adjacent coastal ocean waters (Mayr et al. 1989). The wastewater from about 14,000 companies and millions of people located around the bay area contribute to the bay pollution with an input of approximately 470 tons of domestic sewage plus 5.5 tons of garbage and 150 tons of industrial waste daily (Feema 1990). The study area host the MORio - Microbial Observatory of 


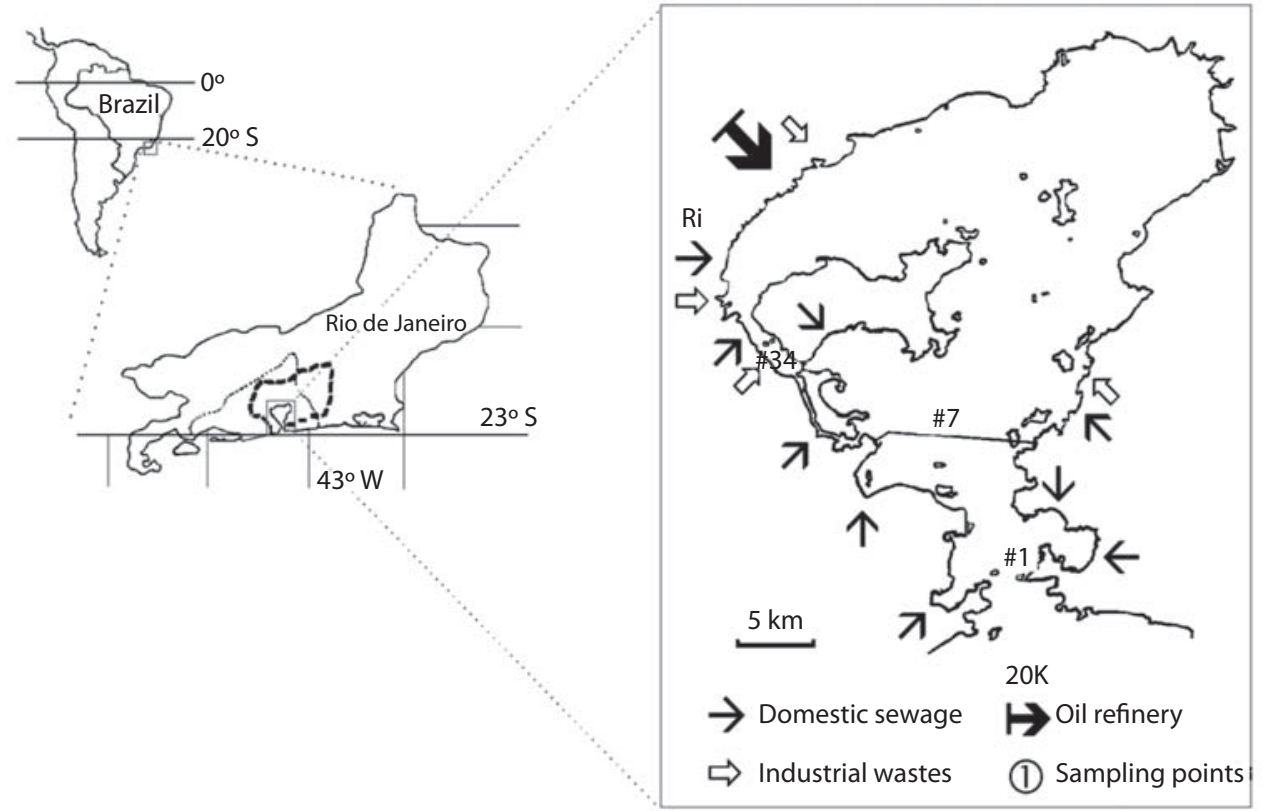

Fig. 7. Guanabara Bay, its drainage basin (---), metropolitan area of Rio de Janeiro (---), Brazil, and sampling sites (MORio observatory).

Rio de Janeiro. Samples are taken along a gradient of polution going from a river well above the estuarine zone, from an inner channel which receives heavily polluted waste water characterized by oil sewage waters (Meniconi et al. 2002, Brito et al. 2006) to seawater $25 \mathrm{~km}$ off the bay's entrance, in the adjacent Atlantic Ocean.

\section{Phytoplankton abundance and diver-} sity: Phytoplankton diversity is currently assessed in different marine systems of Latin America and the Caribbean Basin. Studies presented here are based on phytoplankton net trawls in sub-surface waters (pore size of 20 to $60 \mu \mathrm{m})$. We also present data collected directly from Niskin or GoFlo bottles. Concentrated and non-concentrated samples were fixed with different fixatives (lugol, lugol and glutaraldehyde, and buffered formaldehyde), depending on the type of phytoplankton targeted and on the ecosystem considered. Phytoplankton diversity and abundance is assessed by inverted microscopy counts in sedimentation chambers
(Utermöhl 1958). Nano- and pico-autotrophs (including Eukarya and Cyanobacteria) are studied by means of epifluorescence and/or flow cytometry.

Bacterial dynamics (abundance, production): Bacterial samples are taken from sediment (cores) or water (Niskin bottles), in sterile or acid-rinsed flasks, fixed with buffered formalin and/or paraformaldehyde, and kept in the dark at $4^{\circ} \mathrm{C}$. Samples for FCM counts (Thyssen et al. 2005) are frozen immediately after collection. Samples for epifluorescence counts (Porter and Feig 1980, Kepner and Pratt 1994, Artigas 1998) were filtrated onto $0.2 \mu \mathrm{m}$ black polycarbonate filters (Millipore or Nuclepore). Fluorochromes currently used are DAPI, Acridine Orange, Proflavine and/ or Sybr Green. Subsamples carrying important suspended matter, were pre-treated following Chelvadonné and Godfroy (1997) and Hubas et al. (2007). Bacterial production is estimated from tritiated thymidine (Fuhrman and Azam 
1982) and/or leucine Kirchman (1993) incorporation into cells, performed during simulated in situ incubations. Some enrichment experiments were performed in Uruguayan coastal lagoons, where the heterotrophic bacterial community was exposed to different substrates for $2 \mathrm{~h}$ (leucine, thymidine, glucose and $\mathrm{N}$-acetyl glucosamine) and then the abundance, activity and dynamics of the whole bacterial community were analyzed.

Benthic bacterial communities: Coastal reduced sediment samples were obtained with either a mono- or a multicorer, or using a van Veen bottom grab, for the characterization of macro and megabacteria (Gallardo and Espinoza 2007). Sediment cores were sub-sampled into smaller tubes and kept appropriate temperatures in thermally insulated boxes until their live examination in the laboratory. From the grab samples, sub-samples were obtained from the upper surface. Phase-contrast observations and microphotography were carried out on living material (Gallardo and Espinoza 2007).

Microbial diversity: Fluorescent In Situ Hybridization (FISH) and fluorescence in situ hybridization with horseradish peroxidaselabeled probes and catalyzed reporter deposition (CARD-FISH ; Pernthaler et al. 2004) is used to characterize the main groups of bacteria (Prokarya and Archaea) in Uruguay coastal lagoons, the counts being performed on filters by epifluorescence counts (Piccini et al., 2006). The detailed protocols for bacterial DNA collection, filtration and extraction at the MORIO (Brazil) are described by Vieira et al. (2007 a, b). Water is filtered onto a $3 \mu \mathrm{m}$ filter, which captures colonial microbes, particleattached archaea and also archaeal symbionts from phytoplankton and zooplankton organisms. The free-living planktonic microbes are concentrated on a Sterivex-filter $(0.22 \mu \mathrm{m})$. DNA was prepared by standard methods (e.g., Somerville, 1989).

In the Rio de la Plata and Argentinian shelf study, $3 \mathrm{l}$ of water were filtrated onto $25 \mu \mathrm{m}$, $5 \mu \mathrm{m}, 3 \mu \mathrm{m}$ and $0.2 \mu \mathrm{m}$ polycarbonate filters.
16S RNA from Synechococcus were amplified from DNA using the PCR technique and the oligonucleotides SYN172F y OXY1313R (Fuller et al. 2005). DNA amplified segments were analyzed by electrophoresis and visualized in UV light (Sambrook and Russell 2001). Fragments of $1200 \mathrm{pb}$ were cloned by using the primer GEM-T Easy and sequenced. The result of the phylogenetical analysis was compared with sequences from public data bases, by using BLAST and the CLUSTAL X program and analyzed with MEGA 3.1 software. Amplification of 18S DNA was carried out by PCR and 1750n pb were cloned by EUK F/EUK R primers (Diez et al. 2001, Covacevich et al. 2006). Picoeukaryotes were identified as: Alveolata, Prasyophyceae, Cercozoae, Stramenopiles and uncultured marine picoeukarya. 18SDNAr fragments were amplified (560 pb) and clones of of EUKA1/EUK516rGC (Diez et al. 2001) were selected. DGGE gels (DGGE-2000 CBS Scientific) were used for the detection of the corresponding bands (SybGold staining, Molecular Probes).

BoxA fingerprint patterns were compared at different stations in the Rio de la Plata studies for bacterioplankton. A four-member bacterial consortium, capable of using the synthetic surfactant linear alkylbenzene sulfonate (LAS), was isolated and analyzed by 16S rRNA gene sequencing (more than 1,400 bp) which allowed the assessing of the phylogenetic affiliation of LAS-degrading strains. For the isolation and characterization of the bacterial consortium responsible for the degradation of pollutants in Colombian Caribbean coastal systems, nutrient broth and nutrient agar media (MERCK) were prepared. For selection of tolerant to persistent organic compounds bacterial strains, broth with different concentrations of Diesel fuel and Aldrin hydrocarbon was prepared, according to Jilani and Khan (2004). Analytical grade insecticides (DDT and Aldrin) and diesel fuel were used to test their ability to degrade supplemental substrate. The flasks with hydrocarbon consortium were incubated on a shaker operating at 200 r.p.m for 21 days at ambient temperature $\left(30^{\circ} \mathrm{C}\right)$. Flasks with pesticides consortium were 
incubated on a rotatory shaker at $200 \mathrm{rpm}$ at $30^{\circ} \mathrm{C}$ for 30 days.

\section{RESULTS}

Phytoplankton diversity in Mexican waters: Knowledge about biodiversity of marine phytoplankton in Mexico is still in progress: most of the known diversity of marine phytoplankton and microalgae is the result of prospective and preliminary surveys, not related to a long-term project on the biodiversity of these communities.

Among planktonic microalgae, diatoms (Bacillariophyta) and dinoflagellates (Dinophyta) are the best-known taxonomic groups, either for their relative large abundances, the easy methods to collect them and the resistant covering of most of them.

Other taxonomic groups and size fractions remain rather unstudied, such as the so-called phytoflagellates, the Cyanobacteria and the nano- and picoplankton fractions. Only few new species have been recorded in Mexican marine waters, but many new records have been confirmed. Monographs or revision works on certain genera or groups are done, especially on diatoms and dinoflagellates. The number of taxa recorded is about 1488 and about 211 genera (Hernández-Becerril 2003). Diatoms are the main group, with species described in different regions of the Mexican Pacific (COBC, GC, PTM y GT), Gulf of Mexico and the Mexican Caribbean (Hernández-Becerril, 2003). Dinoflagellates were mainly studied by
Hernández-Becerril and Bravo-Sierra (2004) and Okolodkov (2005), as did other groups: Coccolitphoridae (Hernández-Becerril et al. 2001), Silicoflagellates (Hernández-Becerril and Bravo-Sierra 2001), Cyanobacteria, Raphidophyceae (Band-Schmidt et al. 2004), Parmophyceae (Bravo-Sierra and Hernández-Becerril 2003), Cryptophyceae and Choanoflagellates.

Cyanobacterial and bacterial dynamics off Puerto Rico: Recently collected data on water column bacterial and unicellular Cyanobacteria abundance, salinity, chlorophyll $a$ concentration (Chla), dissolved organic matter fluorescence, turbidity and bacterial productivity provides evidence of the dynamic spatial and temporal patterns present within the area of the insular shelf, mainly driven by seasonal weather patterns. When comparing both sites in W and SW Puerto Rico, we found no great variability in abundance of microorganisms (i.e. Cyanobacteria, Fig. 8a and 8b), even if higher levels were detected in La Parguera. Bacterial productivity was estimated both in dry and wet periods (Fig.s 9a and b), and we compared the levels of dry vs. wet periods. Bacterial production levels were higher in $\mathrm{La}$ Parguera, in coastal areas (Fig. 9b). Bacterial production was highest during the dry season in Mayagüez bay (Fig. 9a). Bacterial productivity and abundance were correlated $(\mathrm{P} \leq 0.05)$ in both sampling sites, during the dry period. The correlation was only significant during the wet period in La Parguera (Fig. 9c and d).

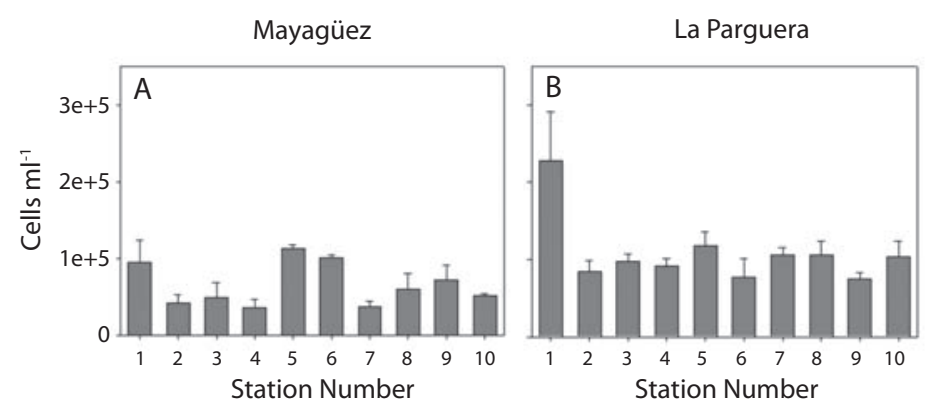

Fig. 8. Abundance of unicellular cyanobacteria in Mayagüez (A) and La Parguera (B), Puerto Rico. 
Average unicellular cyanobacteria showed an abundance of close to $4.5 \times 10^{3}$ cell ml-1 in waters shallower than $50 \mathrm{~m}$ (Fig. 10a). Waters associated to the chlorophyll $a$ maximum (normally close to $75 \mathrm{~m}$ ) did not show a concomitant increase in unicellular Cyanobacteria and unicellular Cyanobacteria suffer a dramatic decrease to negligible numbers in deeper waters. The average bacterial abundance at CaTS station showed a relatively uniform value of approximately $4 \times 10^{5} \mathrm{cell} \mathrm{ml}^{-1}$ in the mixed layer $(<100 \mathrm{~m})$, reaching an abundance of in ca. 100 cells ml-1 down to $200 \mathrm{~m}$. The average bacterial production (Fig. 10b) fluctuated between 0.06-1.5 $\mu \mathrm{g} \mathrm{C} \mathrm{l}^{-1} \mathrm{~d}^{-1}$, during the sampling period. The vertical profile is typified by a linear decrease down to $125 \mathrm{~m}$.
Bacterial and phytoplankton compared dynamics in coastal and shelf systems of F. Guiana: In cruises carried out in littoral, coastal and inner-shelf waters (ELISA cruises), we observed different situations of high chlorophyll $a$ concentrations corresponding to different seasonal periods: wet (June 2004), dry (November 2002, July 2003), and intermediate (March 2003) periods. Chlorophyll $a$ concentrations decreased drastically from coastal to inner-shelf stations excepting in June 2004 and March 2003 (Figs. 11a, b, and c), when concentrations increased in inner-shelf waters. Bacterial abundance did not show any clear trend from littoral to coastal and inner-shelf waters (Figs. 11d, e and f). However, the \% of attached cells (data not shown) decreased

Mayagüez
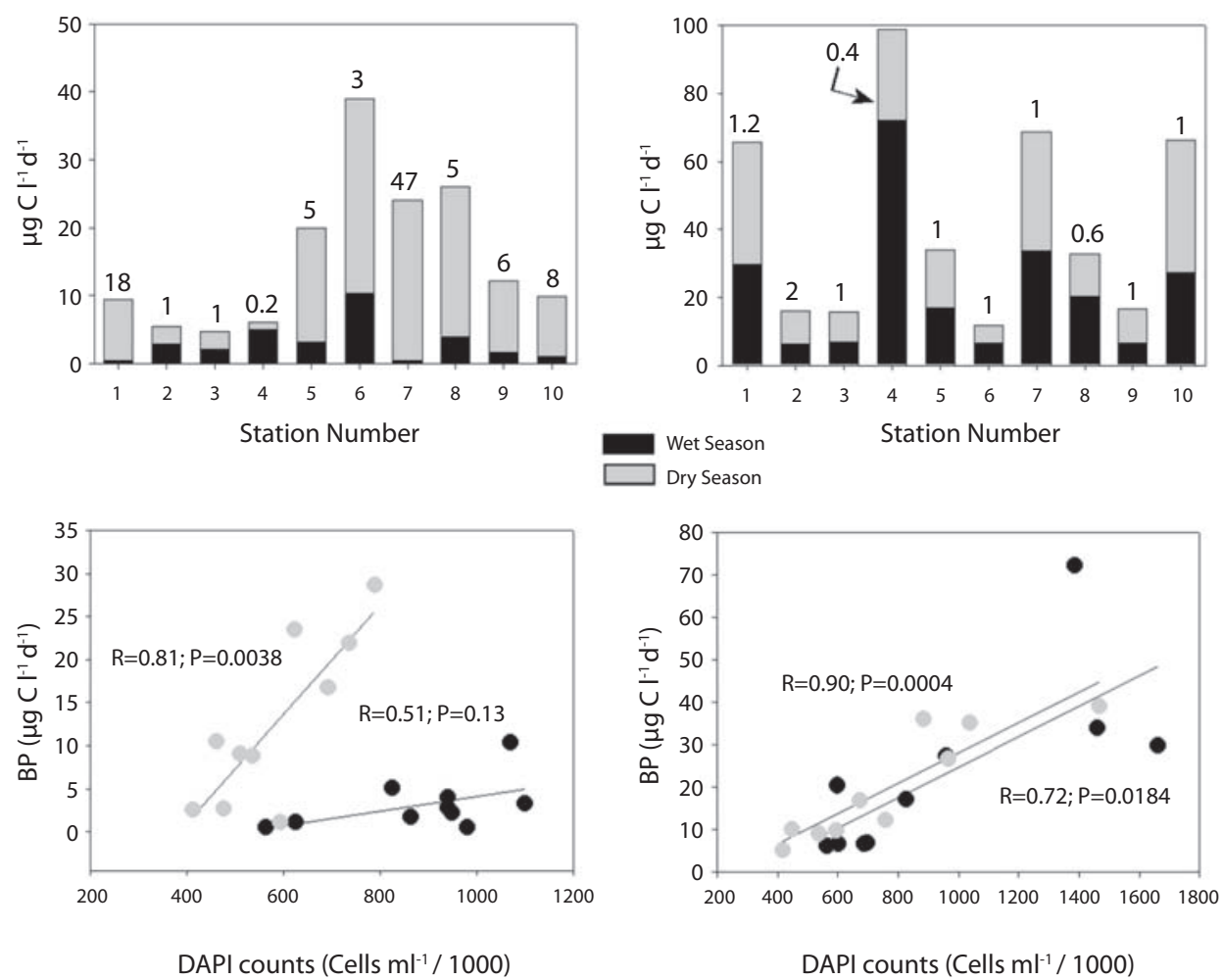

Fig. 9. Bacterial production during the wet (September 2000) and dry (March 2001) season in Mayagüez (A) and La Parguera (B), Puerto Rico. Numbers above the bars for each station represent the ratio of dry/wet bacterial production at the stations specified. Correlation of bacterial production vs. bacterial numbers in Mayagüez (C) and La Parguera (D). 

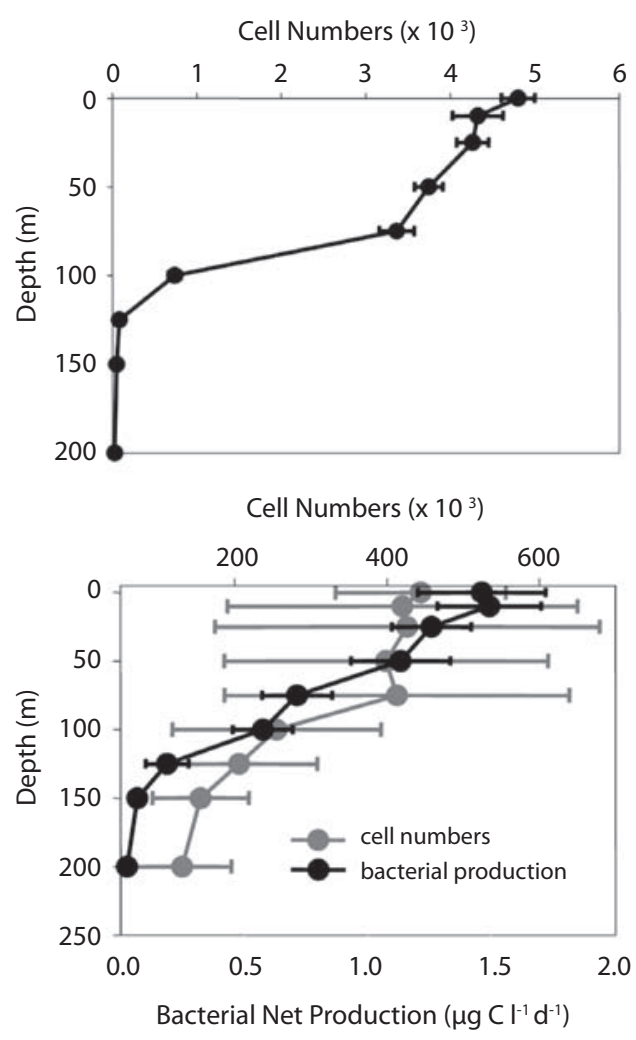

Fig. 10. Vertical profile of average unicellular cyanobacteria at CaTS (Puerto Rico) from September 1999 to August 2001 (A). Error bars represent \pm 1 SE. Bacterial abundance and net production in the Caribbean Time Series (CaTS, B). Abundance data encompass the period of August 1998 to August 2001 while production data covers the period of September 2000 to August 2001. Error bars represent $\pm 1 \mathrm{SE}$.

drastically from littoral to coastal waters, corresponding mainly to cells attached to the important concentrations of suspended matter measured in littoral waters (resuspension of mud banks and fluid mud). Bacterial production levels ranged between 0.1 up to more than $20 \mathrm{\mu gC} \mathrm{l}^{-1} \mathrm{~h}^{-1}$, in littoral and coastal waters, at bloom periods (November 2002, March 2003 and June 2004). The values decreased from littoral to inner-shelf stations (Figs. 11g, h and i), depending on the period and transect considered. However, high levels of bacterial production were also recorded at inner-shelf stations essentially in March 2003 and June 2004.

Phytoplankton diversity indexes were the highest in littoral stations, dominated by diatoms. Three main associations of species were characterized: i) a consortium of species in littoral waters of the three transects (out of the June 2004 period), as well as in the whole SW transect (Approuague), represented by the diatoms Skeletonema tropicum, Thalassiosira sp., et Chaeotoceros saltans; and (ii) a consortium characterizing the inner-shelf waters, represented by the diatoms Guinardia flaccida, Odontella mobiliensis, Odontella reticulata, Thalassionema frauenfeldii and the dinoflagellates Prorocentrum micans and Protoperidinium diabolus, (iii) the indicator species of coastal waters in June 2004, the dinoflagellate Ceratium lineatum together with the diatoms Cyclotella stylorum and Coscinodiscus oculusiridis and the dominant species Pyrophacus sp., Chaetoceros affinis and Cerataulina dentata.

A phytoplankton bloom was detected on the SE mid-shelf stations of the CHICO-1 cruise (October 2003; data not shown), in stations influenced by direct Amazon inputs (Ternon et al. 2005, Artigas et al. 2005, Artigas et al., 2007, Artigas et al. unpubl.). Diatoms (Thalassiosira Levanderi, Skeletonema tropicum, Chaetoceros sp., Pseudonitzchia pungens, Guinardia delicatula) characterized the highest microphytoplankton biomass, associated with the highest concentrations of nano- and picoautotrophs (including Prochlorochoccus sp.), total and high acid nucleic bacterial abundance and production. Bacterial cells also accumulated at the shelf margin in oceanic waters, and at mid-shelf stations out of the phytoplankton bloom period.

On the other hand, the microbial community in mobile sediments of F. Guiana coastal zone is highly diverse (Madrid et al. 2001). Iron oxide respiration is a major pathway for organic matter oxidation, sulfate reduction is responsible for remineralization of $\sim 15 \%$ of organic matter. Chemolithoautotropy was shown to be a major reaction in the mobile sediment carbon cycle. 


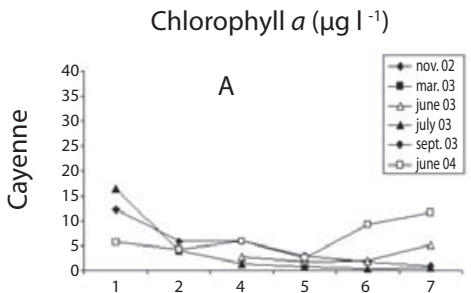

Bacterial Ab. (x $10^{6}{\left.\text { cells } \mathrm{ml}^{-1}\right)}^{-1}$
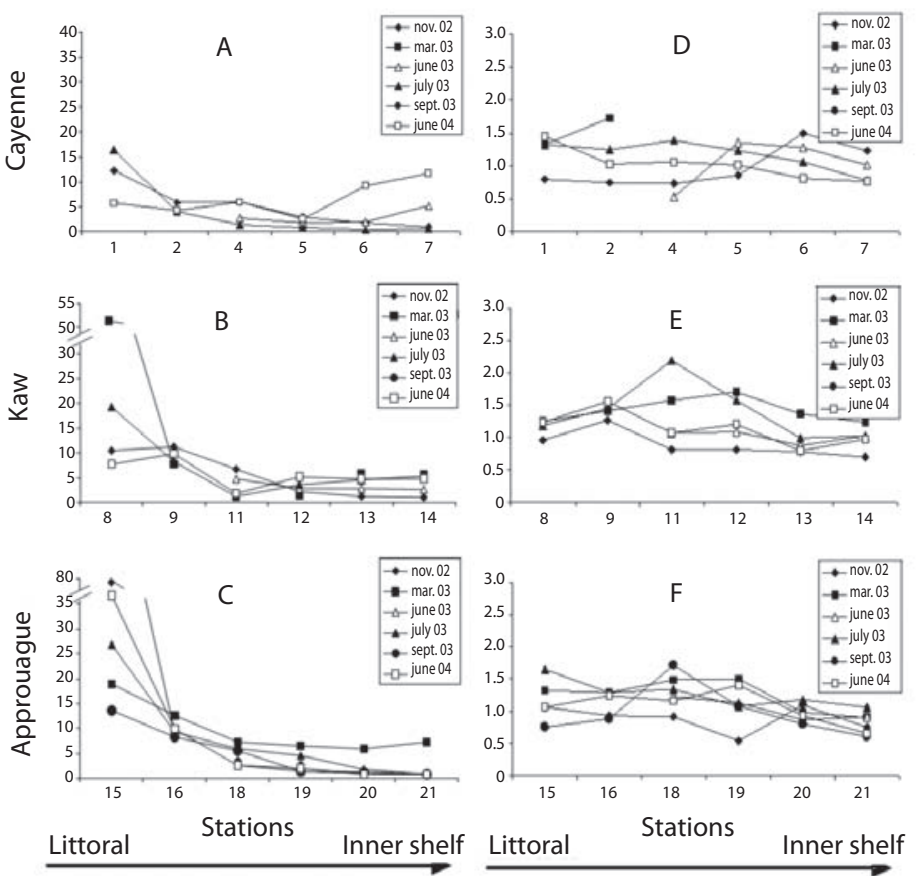

Bacterial Prod. $\left(\mu \mathrm{gCl} \mathrm{Cl}^{-1} \mathrm{~h}^{-1}\right)$
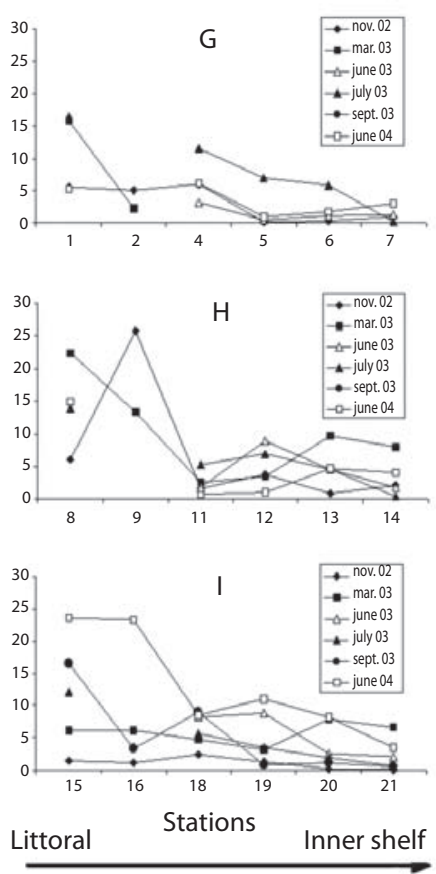

Fig. 11. Chlorophyll $a$ concentrations (left), bacterial abundance (center) and bacterial production (right) in littoral and coastal surface waters off Cayenne (top), Kaw River (middle) and Approuague rivers (bottom) - ELISA cruises (2002-2004), F. Guiana. Each graph represent a transect from littoral (left) to inner-shelf (right) waters.

Coastal Lagoons in Uruguay: During an annual study on the bacterial community performed at Laguna de Rocha (from March 2003 to April 2004). Piccini et al., (2006) found that total bacterial numbers were significantly higher in the brackish water zone during the whole study period. In this area of the lagoon, two conspicuous peaks of bacterial abundances were observed in March and December of 2003, respectively (Fig. 12). Regarding the activity and composition of the bacterial community, the dominant bacterial group in both zones of the lagoon was the Alphaproteobacteria. After an intrusion of marine water, members of the marine SAR11 lineage became abundant in the brackish-water zone and were apparently distributed over the lagoon during the following months (Fig. 13a), until they constituted almost 30\% of all prokaryotic cells (Fig. 13b). In March, the microbial assemblage of the lagoon was dominated by a single alphaproteobacterial species, Sphingomonas echinoides. This species was detected concomitantly with the first records of blooms of filamentous cyanobacteria. In December, a pronounced maximum of bacterial activity was detected in both physico-chemical compartments of the lagoon (Fig. 12b). In the freshwater zone, this highly active microbial assemblage was a mix of the typical bacteria lineages expected in aquatic systems, but in the brackish zone a bacterial genotype with $>99 \%$ similarity to the facultative pathogen gammaproteobacterial species Stenotrophomonas maltophilia formed $>90 \%$ of the bacterial assemblage (Piccini et al. 2006).

In a study performed by Alonso et al. (unpubl.) in Laguna Castillos, the authors found significantly higher substrate incorporation in the Chafalote for three of the tracers, with a 


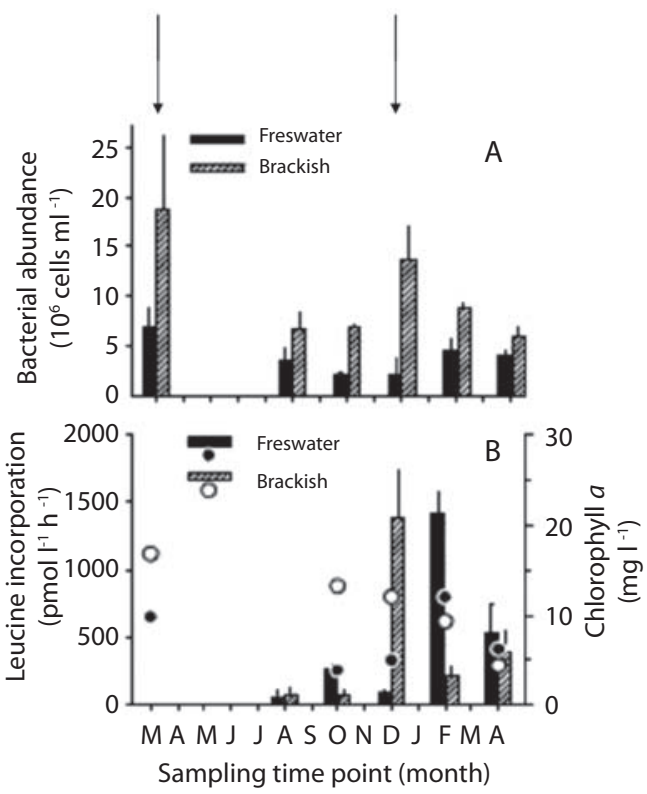

Fig. 12. Total prokaryotic cell numbers in the two zones of the Rocha lagoon, Uruguay (A). Bulk leucine incorporation rates (bars) and concentrations of chlorophyll $a$ (Chl a; circles) (B). On two occasions, samples were lost: March 2003 (leucine incorporation) and August 2003 (chlorophyll a). From Piccini et al. (2006). The arrows at the top indicate maximum bacterial abundance in brackish waters.

maximum observed in the samples incubated with leucine (data not shown). In Chafalote, leucine was preferentially incorporated, whereas in the main body of the lagoon, both leucine and glucose were similarly incorporated. In both compartments the lowest incorporation values were found for the samples incubated with $\mathrm{N}$-acetyl glucosamine, while thymidine was incorporated in a similar rate.

\section{Microbial diversity in the Rio de la Plata} estuary, plume and in the Argentinian shelf: The set of variables available encompasses total picoplankton cell number estimation, chlorophyll $a$ and phaeophytin, together with the abundance and distribution of hydrocarbon degrading bacteria. Phytoplankton of $<5 \mu \mathrm{m}$ in size was composed mainly by Synechococcus, Chlorophyte, Haptophyte and Cryptophyte, and their dominance was related to the complex

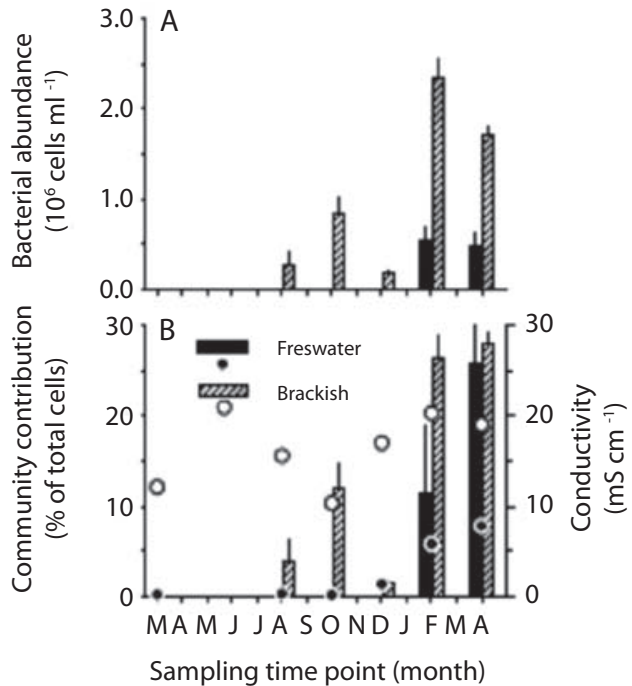

Fig. 13. Numbers of cells (A) and relative abundances (B) of bacteria from the marine SAR11 clade in the two zones of the Rocha lagoon, Uruguay. For comparison, panel B also depicts the conductivity data (circles). From Piccini et al. (2006).

environmental features of the Río de la Plata estuary and adjacent zones (Figs. 14a and b). During the seasonal and monthly survey at the EPEA station, Synechococcus spp abundance ranged from 750 to $171 \times 10^{3}$ cells $\mathrm{ml}^{-1}$ (Figs. 15a and b). High values were related to the temperature and the stability of the water column. The analysis of the sequences indicated that the clones were part of the Clade I (Fig. 16) described within the ITS system (Rocap et al. 2002), being part of the sub clade 5.1 previously known as the marine clade A (MC-A) (Everroad et al. 2006). By comparing microscopic observations with clone sequences analysis and distribution of bands in DGGE gels, we concluded at the highest diversity of picoeukarya at intermediate stations, and the lowest genetic diversity in the offshore area, the main groups being represented in Fig. 17.

The bacterioplankton abundance varied

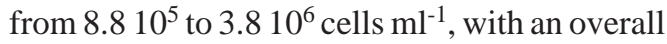
average of $2.64 \times 10^{6}$ cells $\mathrm{ml}^{-1}$. The interaction of different environmental parameters was 

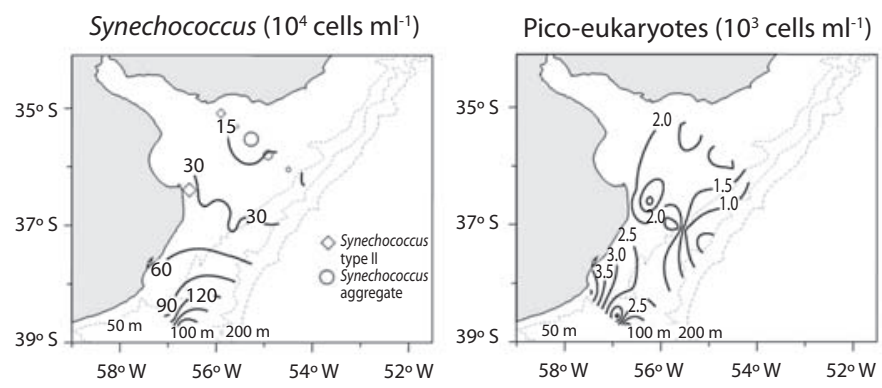

Fig. 14. (A) Distribution of Synechococcus $\left(10^{4}\right.$ cell ml-1) and (B) distribution of pico-eukaryots $\left(10^{3}\right.$ cell $\left.\mathrm{ml}^{-1}\right)$ in the Rio de la Plata and Argentinian adjacent shelf.
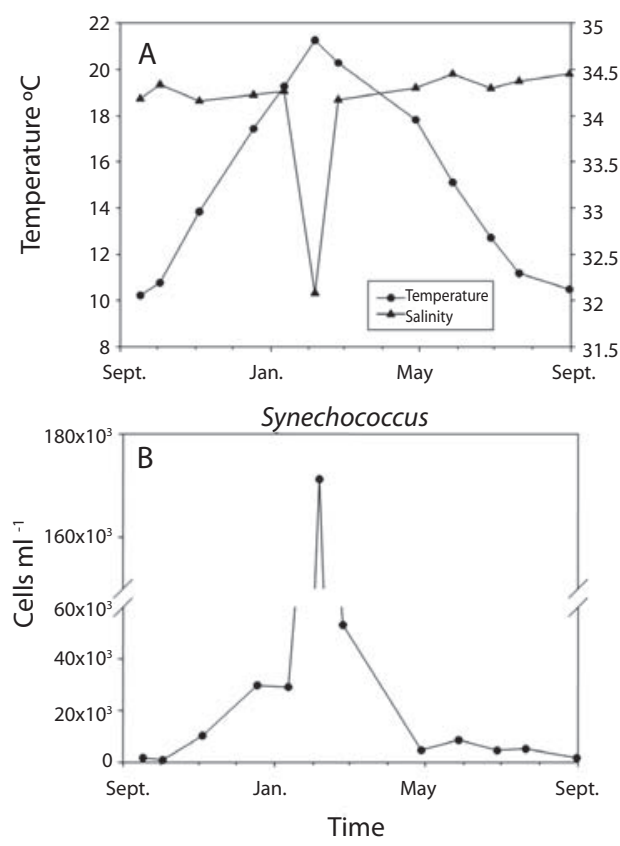

Fig. 15. (A) Temperature and salinity, and(B) Synechococcus abundance during anual cycle at EPEA station, in te Argentinian shelf.

evidenced as affecting the community at mixohaline and adjacent marine water of the Rio de la Plata system (Figs. 18a and b).

Marine bacteria in OMZ sediments in the Eastern South Pacific (ESP) and in the anoxic Cariaco Basin: The Humboldt Current Ecosystem is one of the least studied large marine ecosystems of the world, even though research efforts increased in the area through recent local and international programs. At the Central Chilean Time-Series Station 18 (88 m depth), in the austral summer of 2004, of a complex new community of large filamentuous bacteria (from here on referred to as "macrobacteria”) was discovered, their length (from 1 to $10 \mu \mathrm{m}$ in diameter and from 10 to several hundreds of $\mu \mathrm{m}$ in length) being at least one order of magnitude smaller than the so called "megabacteria”, in sediments under the Oxygen Minimum Zone (OMZ) of the region which is accompanied by extensive hypoxic and anoxic sediments (Gallardo and Espinoza 2007). Microbial community in deep sediments of the Cariaco basin is dominated by Proteobacteria involved in the sulfur cycle. Sulfate reduction is the major pathway of anaerobic organic matter oxidation Chemolithoautotropy was shown to be a major reaction at the $\mathrm{H}_{2} \mathrm{~S} / \mathrm{O}_{2}$ transition zone (Chistoserdov et al. unpubl.).

Hydrocarbon degrading bacteria in mixohaline areas of the Rio de la Plata: Previous results of BoxA fingerprint patterns showed that the overall isolates profiles were diversified within the different locations, and each presented DNA fragments from 0.2 to $4 \mathrm{~kb}$. Significant differences (Kruskall-Wallis test, $p<0.01$ ) in counts of hydrocarbon degrading bacteria were detected, (Fig. 19a and b) by considering different areas of the estuarine mixohaline zone, their abundance ranging from $10^{5}$ to $10^{6}$ 


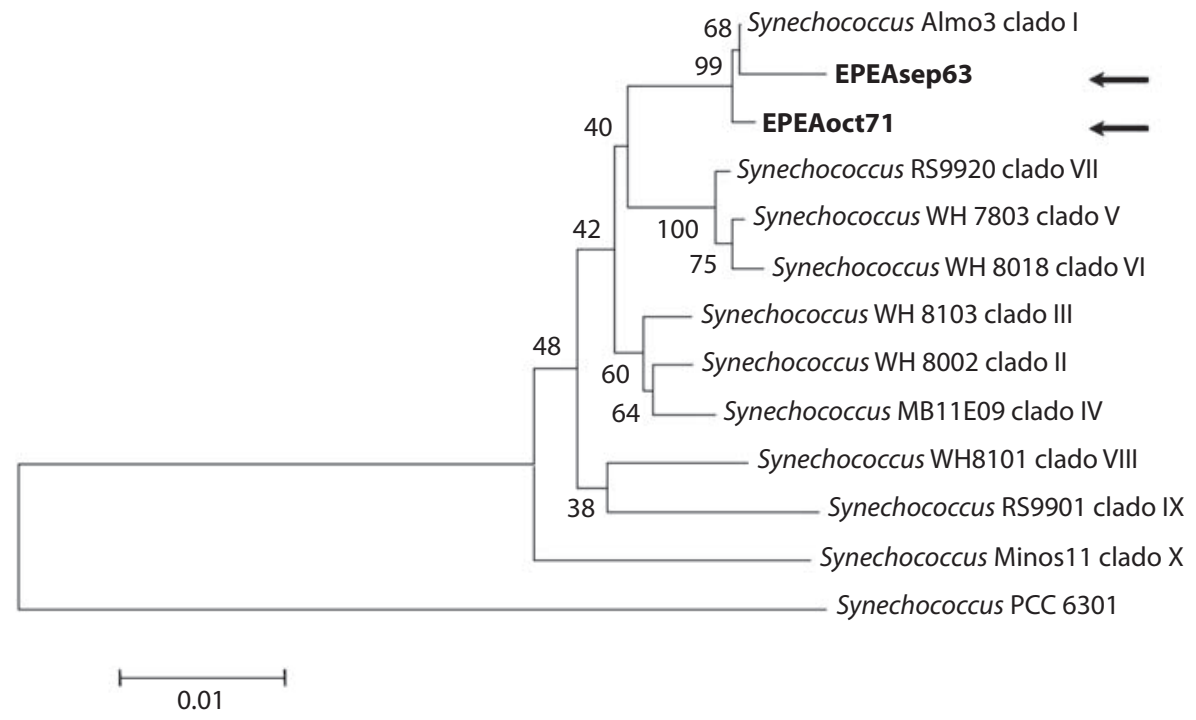

Fig. 16. Phylogenetic analysis of ADNr 16S sequences belonging to Synechococcus. The tree was constructed by NeighborJoining (NJ) model. Synechococcus PCC 6301 was the outgroup.

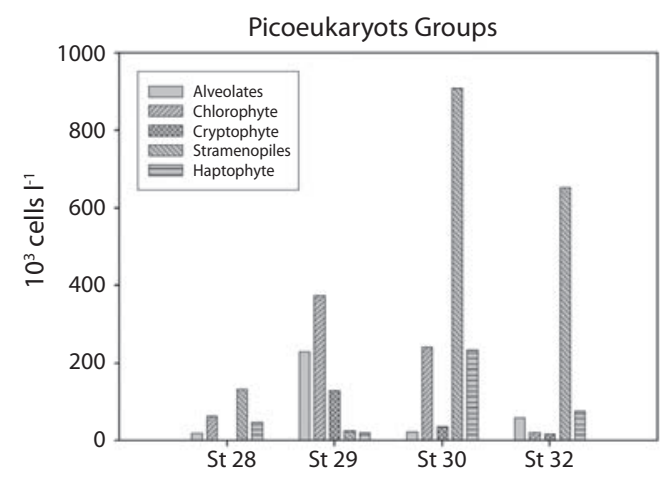

Fig. 17. Principal groups of pico-Eukarya in stations of the Argentinian shelf (off Península Valdéz).

CFU ml-1, high values being associated with sample stations affected by the presence of these contaminants (details of the stations not shown, Costagliola et al. unpubl.). A fourmember bacterial consortium capable of using the synthetic surfactant linear alkylbenzene sulfonate (LAS) was isolated and analyzed by 16S rRNA gene sequencing (more than 1,400 bp), which allowed the assessment of the phylogenetic affiliation of LAS-degrading strains.
The topology shown in Fig. 20 indicated that within the Aeromonas monophyletic group, strains DBS2 and DBS4 formed a clade with A. caviae, with $89 \%$ recovery in bootstrap analysis. In the Pseudomonas group, isolate DBS11 and $P$. alcaliphila formed a clade grouped with $74 \%$ bootstrap support. The cladogram also showed that DBS13 was closely related to $V$. parahaemolyticus and V. alginolyticus.

Oil degrading bacterial communities in sediments off the Venezuelian coast: Thirty isolated samples were cultivated from shelf systems off the Orinoco River delta: Gramnegative rods predominated and almost 100\% of them were able to grow on mineral oil as a C source, in an area already exploited by the Trinidad and Tobago Oil Company, explaining probably the presence of oil-degrading native bacteria (Malavé et al. 2005). Fig. 21a shows a Transmission Electron microphotograph of the isolate C12, a Gram-negative rod cultivated from offshore sediments ( 1100 m depth). A second type of bacterium was isolated from water samples off the Orinoco River delta: a Gram-positive coccoid form that grows in 
$\mathrm{A} \sqcup$ cells $\mathrm{ml}^{-1} \rightarrow$ Chl-a $\rightarrow-{ }^{\left({ }^{\circ} \mathrm{C}\right)}$

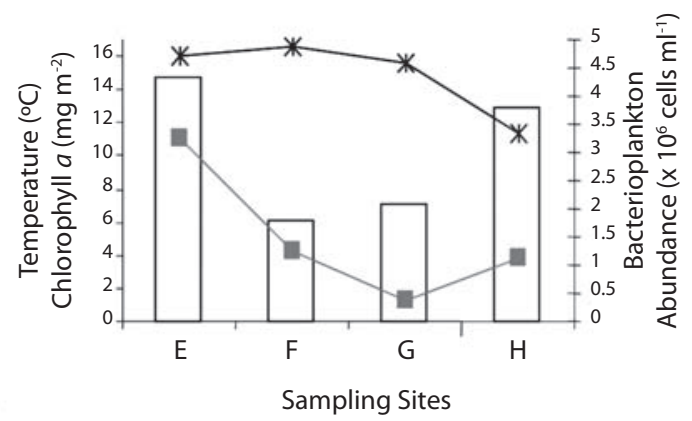

B cells ml-1 $₫$ sal

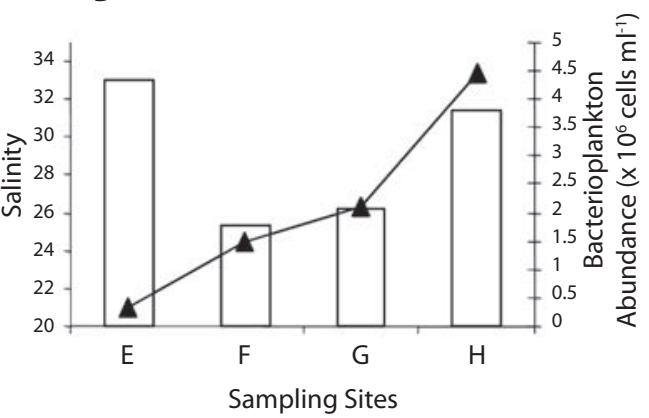

Fig. 18. Distribution of bacterioplankton abundance, chlorophyll $a$ concentration, and environmental parameters in the

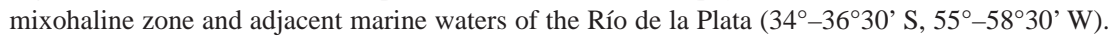
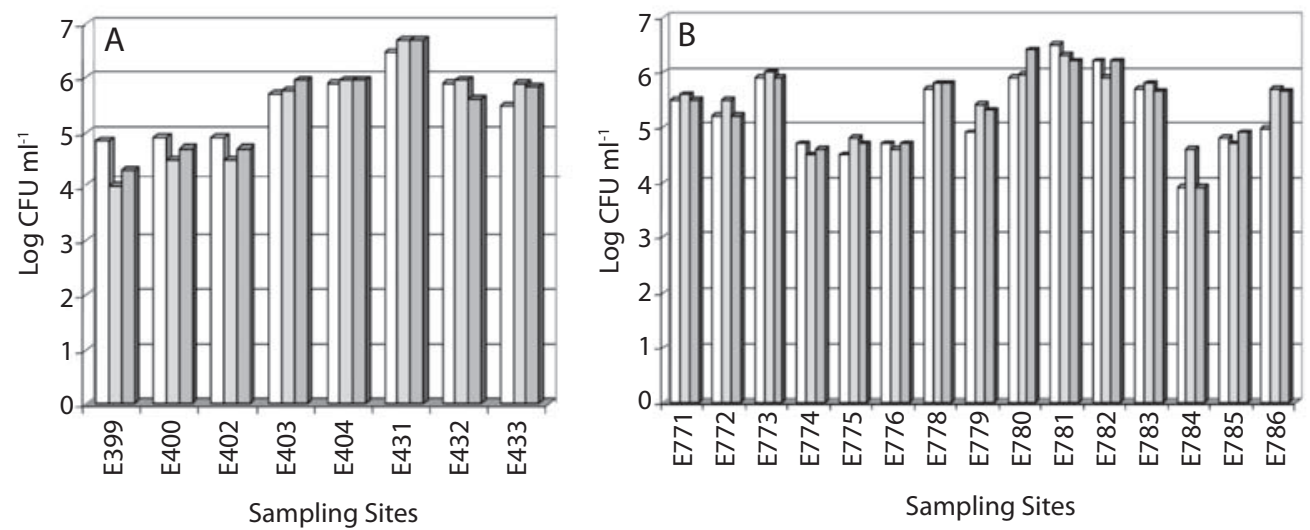

Fig. 19. Abundance of hydrocarbon degrading bacteria in mixohaline waters of the Río de la Plata.

tetrads (Fig. 21b). This bacterium was capable of growing in a minimum medium with mineral oil as the only C source. The PCR analysis of the RNAr 16S and the biochemical tests identified this bacterium as the genus Micrococcus (Gueneau \& Suárez unpubl.).

\section{Bacterial diversity in threatened coastal} sediments of the Colombian Caribbean: Sixty four bacterial strains were isolated from sediment samples and underwent a selection process with the purpose of choosing competitive bacteria to evaluate their ability to degrade hydrocarbons (Diesel fuel) and organochlorinated pesticides (Aldrin). Mixed bacterial cultures grown on medium with hydrocarbons were able to degrade up to $68.61 \%$ of the n-alkanes fraction in the diesel fuel after 21 days and $23.54 \%$ of the aliphatic hydrocarbon degradation were due to abiotic factors (Gómez et al. 2006). From the test with bacterial isolated of the CGSM, in which $60 \mathrm{ng} \mathrm{l}^{-1}(100 \%)$ of Aldrin were inoculated, $30.9 \%$ of pesticide degradation were attributed to external factors (abiotic) and 20\% were attributed to the degradation carried out by a bacterial consortium including Bacillus licheniformis, B. cereus, B. pumilus and Enterobacter cloacae. A greater growth of this bacterial consortium appeared during the first fifteen days of exhibition to 


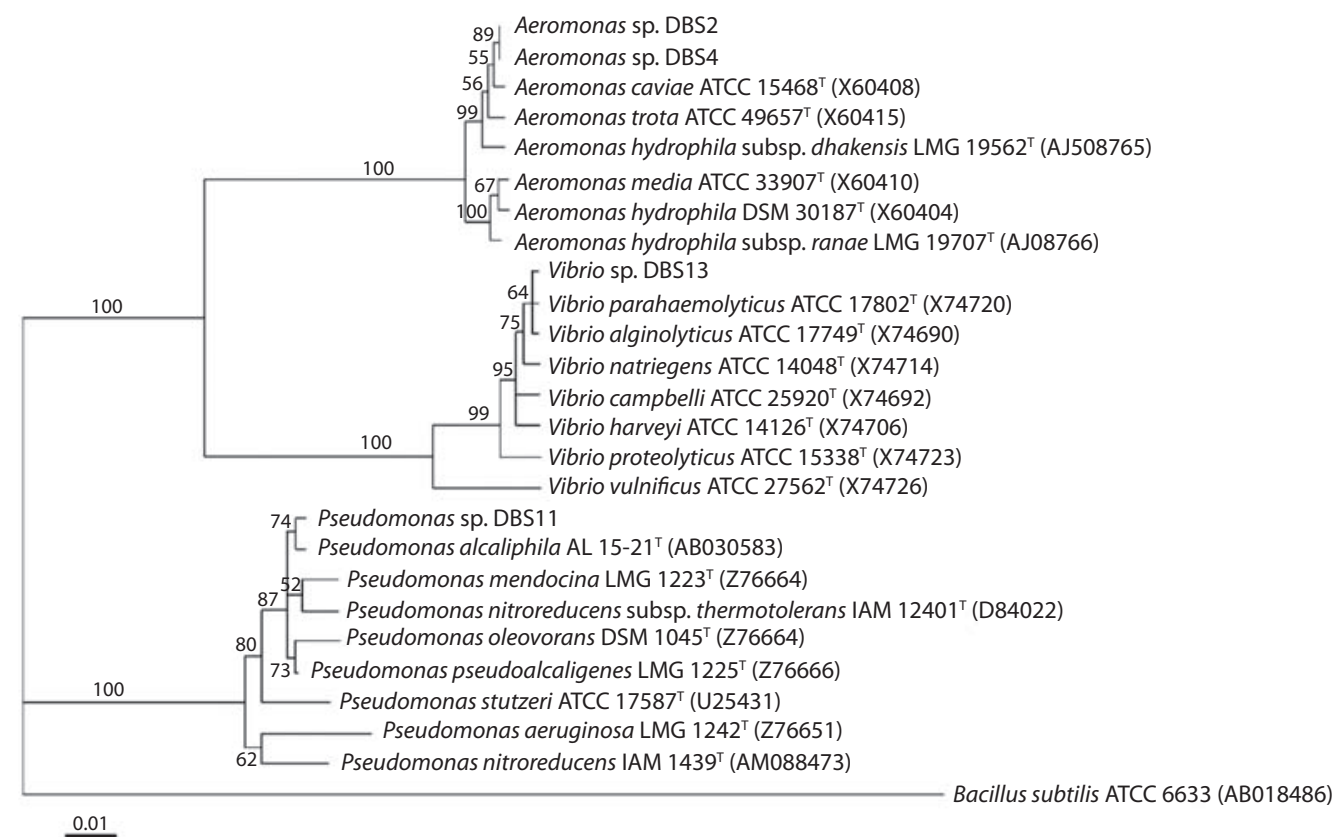

Fig 20: Phylogenetic tree indicating the affiliation of LAS-degrading strains and related bacterial taxa. The tree shown is the result of an NJ bootstrap analysis (1000 replications) using 16S rRNA gene sequences. Numbers at internal nodes are bootstrap support values (\%). In parentheses are indicated GenBank accession numbers. Bacillus subtilis was chosen arbitrarily as the outgroup for the phylogenetic tree.

Aldrin, with $50 \times 10^{9} \mathrm{UFC} \mathrm{ml}^{-1}$ counts, while the consortium without Aldrin remained stable during the first 7 days, with counts of $10 \times 10^{6}$ UFC $\mathrm{ml}^{-1}$ (Gómez et al. unpubl.).

Microbial diversity at the Microbial Observatory of Rio de Janeiro: Weekly sampling was performed from 1998-2000, but a monthly sampling frequency was afterwards established for the 2002-2005 period. Since then, water and sediment samples are taken twice a month. Gene libraries revealed that the phylotype identification was consistent with environmental setting. Archaeal phylotypes found in polluted anoxic waters and in more pristine waters were closely related to organisms that have previously been found in these environments. However, the inner bay Archaea were related to organisms found in oil, industrial wastes, and sewage, implying that water pollution controls Archaeal communities in this system (Vieira et al. 2007a). The detection of a substantial number of uncultured phylotypes suggests that Guanabara Bay harbors a pool of novel Archaeaplankton taxa, that justifies a more detailed study onto this diversity. We have also observed that at the interface between waste-polluted freshwater and coastal marine waters in Guanabara Bay estuary has revealed remarkably high Archaeaplankton species diversity. Concerning Eubacterial diversity, a correspondence analysis demonstrated inverse correlations between diversity and bacterial abundance and production, suggesting that bacterial communities are specific and heterogeneous over abiotic parameters in Guanabara Bay estuarine complex (Vieira et al. 2007b).

\section{DISCUSSION}

Phytoplankton diversity and dynamics studies: New techniques, methods and 

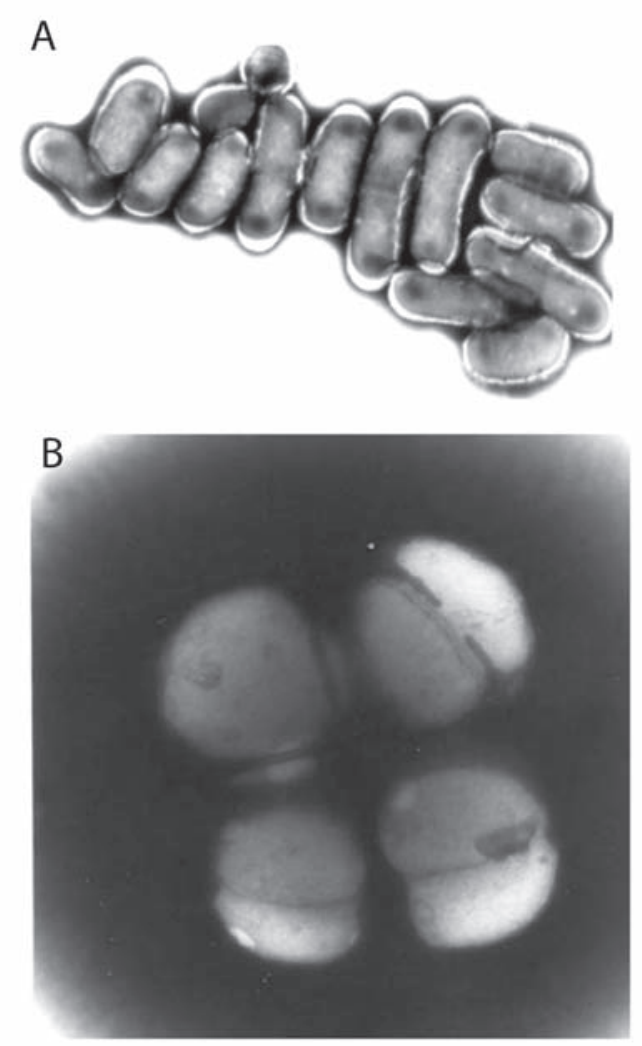

Fig. 21. (A) TEM Microphotography of bacterial strain C12 isolated from sediments of $1,100 \mathrm{~m}$ depth and (B) TEM Microphotography of the bacterial strain C8 isolated from sediments of 40m depth, off the Orinoco River Delta, Venezuela.

approaches are in process to improve our knowledge on phytoplankton diversity in coastal and ocean waters. The use of a wide range of methods and techniques that have become available, invite to study all groups in a better and more systematic way, including new protocols for electron microscopy, molecular tools and remote sensing facilities.

The biodiversity of marine phytoplankton and microalgae can be considered as rather medium in Mexican waters, even if some new species are still found. New records were annotated, some of them are under speculation about being exotic or resulting of contamination by anthropogenic activities. Perspectives are wide if various professionals and institutions work together in collaboration and define goals in time and space.

In littoral and coastal systems of French Guiana, phytoplankton main indicator and dominant species are comparable to those found in tropical Atlantic waters of Venezuela (Margalef and Gonzalez-Bernaldez 1969, Margalef 1972, Paulmier 1993, Agard et al. 1996) where diatoms dominate littoral and coastal waters and dinoflagellates are more important in marine waters (and cyanobacteria, important in mostly oceanic waters). According to Margalef (1972) and Agard et al. (1996), both studies in the Orinoco River plume and adjacent areas, as for Paulmier (1993) and Shipe et al. (2006) in the Guianese and Amazon Plume shelf and ocean waters respectively, salinity and Si structurate phytoplankton assemblages in systems of great continental influence. In our study in Guianese coastal and shelf waters, diatoms dominated in all the different situations and locations sampled. However, a spatial and a temporal variability was detected between stations considered, littoral vs. inner-shelf stations, coastal vs. outer shelf, SW vs. NE stations, dry vs. wet period, and June 2004 (when dinoflagellates represented a great amount of all phytoplankton) vs. the rest of the periods sampled. Moreover, particular studies including nanoand picoplankton were developed in shelf systems as during the CNB retroflexion period in French Guiana, when Prochlorocococcus spp., Synechococcus spp., and nano- and picoeukaryotes detected by flow cytometry completed the study of the auotrophic community, and where co-responsible of the important bloom situation described (Ternon et al. 2005, Artigas et al. 2005). Micro-algal communities are also studied in mud banks and littoral zones in F. Guiana (Sylvestre et al. 2004), as well as in open ocean systems submitted to the Amazone influence (Carpenter et al. 2004, Capone et al. 2005, Shipe et al. 2006, Foster et al. 2007, Hewson and Fuhrman 2007), underscoring the importance of $\mathrm{N}_{2}$-fixing colonial cyanobacteria (Trichodesmium sp.) or endosymbiotic cyanobacteria (Richelia sp. endosymbiotic 
of diatoms of the genus Hemiaulus and Rhisozolenia). Studies carried out on longer time scales and wider spatial ranges would give us a clearer picture of the whole phytoplankton community dynamics and productivity in these systems of great continental influence.

The first molecular identification of Synechococcus spp. was carried out at the Argentinian shelf. The two sequences of Synechococcus 16SDNAr corresponded the strictly marine monophyletic group 5.1 (MC-A, Everroad et al. 2006). Coinciding with other microscopic studies and published data, members of this genus of cyanobacteira represent a conspicuous component of the picophytoplankton and can significantly contribute to the phytoplankton biomass. The diversity of picoeukarya was high at intermediate shelf stations in the Patagonian system. These studies are coupled to bacterioplankton dynamics determination. Recent studies on phytoplankton dynamics complete this picture of phytoplankton diversity and dynamics in South American estuarine systems, including those of Calliari et al. (2005) and Licursi et al. (2006) in the estuarine systems of the Rio de la Plata. On the other hand, phytoplankton studies, together with food web and biogeochemical fluxes estimations are intensively carried out in the upwelling system off Chile (Herrera \& Escribano 2005, Anabalón et al. 2007, Böttjer \& Morales 2007, González et al. 2007, Morales et al. 2007), as well as in subtropical lagoons in Southern Brazil, focusing in phytoplankton dynamics and trophic fate (Abreu et al. 1995, Abreu et al. 2007), and in South Atlantic oceanographic frontal systems (Brandini et al. 1996). We underline the importance of combining both traditional microscopy assessments combined with cytometry or epifluorescence counts and molecular sequencing for the monitoring and identification of dominant and rare cyanobacteria and auotrophic eukaryotes present in the different ecosystems considered. These studies could be joined to current monitoring efforts carried out in different systems for the detection of phytoplankton outbursts and/or harmful algal blooms, in the field and/or by remote sensing, as the ANTARES network (www.antares.ws), from Mexico to Argentina.

Autotrophic and heterotrophic picoplankton compared dynamics in the Caribbean: Previous work has demonstrated significant changes in chlorophyll $a$, turbidity, phycoerythrin, nutrients, salinity, bacteria and unicellular cyanobacteria abundance in marine waters of SW Puerto Rico (Otero 2001), characterized by a rich ensemble of environments such as mangroves, seagrass meadows, coral reefs, submerged bare-sand and muddy basins, and coastal lagoons fringed by the oceanic seascape to the South. The bacterial community grew more efficiently during the dry season in Mayaguez Bay. No seasonal changes were evident in La Parguera. According to the data obtained for bacterial productivity in both $\mathrm{La}$ Parguera and Mayagüez sites, substrate would be of better quality in dry periods for heterotrophic bacteria, especially in Mayagüez site. Although not shown here, cells found in the shallower waters were smaller than those associated to the chlorophyll maximum. The change in abundance and size indicates the presence of two different cyanobacterial populations at CaTS, small size population on the upper region of the mixed layer and larger less abundant cells associated with the depth of the chlorophyll maximum. The larger variation observed in the mixed layer for bacterial abundance values is the result the environmental conditions found during each sampling, which is driven by the observed climatology that includes the Orinoco and Amazon river influx into the Caribbean basin (Corredor and Morell 2001).

Heterotrophic bacterial dynamics in estuarine and coastal systems submitted to important continental inputs and phytoplankton blooms in South America: A spatial distribution pattern of bacterial heterotrophic production was described in F. Guiana littoral and coastal waters affected both by the amounts of allochtonous material and phytoplankton outbursts (littoral and inner shelf waters), but not necessary linked to the bacterial abundance 
distribution. Therefore, bacterial abundance would be regulated by grazing pressure (Billen et al. 1990), as in other tropical systems (Alongi 1998). Bacterial production was also apparently linked to primary production (data not shown), at least during some bloom periods (as March 2003). Bacterial productivity ranged from an average of $0.04 \mathrm{~h}^{-1}$ in shelf waters during the mid-shelf bloom, typically found in coastal temperate waters when phytoplankton blooms occur (Artigas et al. 2000, Lamy et al. 2006) up to $0.20 \mathrm{~h}^{-1}$ (November 2002 littoral and coastal waters and June 2003 inner shelf waters) and to more than $0.30 \mathrm{~h}^{-1}$ during both bloom situations in coastal waters (March 2003 and June 2004). Bacterial dynamics appeared to follow phytoplankton distribution, especially when phytoplankton underwent relatively short-term outbursts. Their ecological role is to fuel the "microbial loop" both in shelf than in coastal and estuarine waters, where benthic-pelagic coupling is enhanced. The high productivity values recorded (compared to other coastal systems) are probably related to important mineralization processes that would be linked to the important amounts of phytoplankton and fresh-derived organic matter that characterize these areas. In the Rio de la Plata estuarine zone, the temporal and spatial dynamics of bacterioplankton abundance is currently monitored within the monitoring of threatened sites.

The remineralization of both terrestrial and marine derived organic carbon in the nearshore and estuarine waters would be more efficient in maximum turbidity areas, a great proportion of this degradation being attributed to attached bacteria being important in other estuarine systems (Artigas 1998, Goosen et al. 1999), and more specially in mobile mud systems (Aller et al. 2004). Moreover, the bacterial diversity in these coastal mud deposits along the French Guiana coastal area would be high (Madrid et al. 2001), suggesting a substantial number of metabolic pathways or potentialities of these attached bacterial community. Remineralization of the large quantity of terrestrial and marine organic matter is highly efficient and remarkably complete within the fluid muds and appears to be due to intense microbial chemolithotrophic (dark $\mathrm{CO}_{2}$ fixation) metabolism. The presence of a fully functional, globally significant, net $\mathrm{CO} 2$ producing internal carbon cycle in these vast $(1,600 \mathrm{~km})$ belt of mobile mud environments makes one wonder about what the temporal and spatial dynamics of the mobile sediment communities could be, and about what would be the contribution of entrapped water column bacteria that is responsible for aerobic heterotrophic metabolism in waters and suspended particles to the sediment bacterial community.

\section{Bacterial diversity in coastal subtropi-} cal lagoons: Laguna de Rocha and Laguna Castillos are highly productive coastal lagoons of Uruguay, which although being protected areas are increasingly threatened by human activities in their catchments. Both lagoons are very important nesting sites for migratory birds and the support of small-scale fisheries. During the recent years there have been dramatic changes in land use, especially around Laguna de Rocha. These changes included the first records of blooms of potentially harmful cyanobacteria (Conde et al. 2004) and bacteria (Piccini et al. 2006). Moreover, an increase in the area covered by aquatic plants has also been detected (Bonilla et al. 2004). The two assessed lagoons differ in the extent of the marine influence they receive. For example, in Laguna de Rocha the changing salinity, which depends on the hydrological regime, is one of the potential and relevant structuring factors for bacterial populations. In addition, another important factor is the organic matter source inputs from the catchments, which varies according to the water salinity. It is possible that high input of nitrogen compounds (such as commercial fertilizers commonly used in agriculture) in combination with increased influx of organic carbon by terrestrial runoff might induce the development of large populations of potentially pathogenic bacteria. Since the high bulk bacterial activity during the $S$. maltophilia dominance coincided with a peak in ammonium concentration, we speculate that the dominance and activity of 
this species in the brackish zone of the lagoon could also be related to this nutrient. In addition, marine intrusion events would also alter the community composition of the lagoon by carrying bacterial populations from the ocean. On the other hand, Laguna Castillos does not receive a direct influence from the sea, and we hypothesize that the different humic content and turbidity in both lagoon compartments would be responsible for the different patterns of activity detected for the different tracers.

Additional studies in Laguna de Rocha and Laguna Castillos are in progress, addressing the role of different carbon sources in the composition of the bacterial community by microautoradiography (MAR) combined with FISH (MAR-FISH). This technique can be used to simultaneously examine the phylogenetic identity and the relative or actual specific activity of microorganisms within a complex microbial community at a single-cell level. As well, the relevance of top-down mechanisms (predation by protists) are considered as a structuring force for the bacterial assemblage.

\section{Bacterial diversity in Oxygen Minimum Zones (OMZ) and in Oxic-Anoxic inter-} faces: The finding of the macro- and also megabacterial communities in the OMZ under different conditions attracted new international collaboration and further new knowledge on the microbial community structure is being added. Particular mention is made of the recent finding of Planktomycetales, Verrucomicrobia and Chlamidieae in the same environment (Blair et al. 2006) and of anammox (Kuenen et al. pers. comm.), and other macrobacteria bacteria in Thioploca sheaths. Efforts have been initiated to elucidate the potentially varying phylogenies and physiologies among these novel large bacteria with respect to their spatial and temporal (seasonal and inter-annual) variations at the shelf of Central Chile and the adjacent Bay of Concepción. Microbial dynamics is intensively explored in central Chile (Graco et al. 2001, Cuevas et al. 2004, Grob et al. 2007, Hernández et al. 2007, Levipan et al. 2007) and in the Peruvian upwelling system (Hamersley et al. 2007), related to OMZ and big upwelling productivity and remineralization patterns. On the other hand, through the CARIACO basin program, we have access to vast amounts of historic data that address time variations in the vertical distribution of hydrographic properties, bacterial biomass, FISH profiles, bacterial productivity, chemlithoautotroph and sulfatereducer counts (based on real-time PCR data), fatty acid cycling, hydrogen sulfide, nitrate, dissolved and particulate iron and manganese concentrations, etc. Carbon fluxes are specially targeted within current studies (Muller-Karger et al. 2004). Preliminary DGGE analysis indeed indicates that overall composition of prokaryotic microbial communities in different locations will be different, although several prominent members of the communities (such as sulfide oxidizing $\gamma$-proteobacteria) do persists over time and space. Isolation of nucleic acids for molecular analysis from CARIACO samples started since November 1996. Thus, the questions to be addressed now would be: "What kind of bacteria are mediating dark $\mathrm{CO}_{2}$ fixation and what are the possible electrons sources they use?” And a more general question: "Could the diversity be connected to metabolic functions of the community?”. Moreover, protists diversity began to be assessed by novel molecular methods in this particular environment (Stoeck et al. 2006) and would complete the assessment of the whole microbial diversity in this peculiar environment.

Bacterial and Archaeal dynamics in threatened and polluted systems: Petroleum is one of the major pollutants of marine environments; a vast amount of hydrocarbons is being discharged from industries or from accidental oil spills that are continuously released into the ocean. These compounds subsequently undergo modification by either physicochemical or biological processes. Research studies have revealed that microbial degradation processes that detoxify pesticide contaminants can be effectively used to overcome the pollution problems (Bhadhade et al. 2002). Microbial activities allow the conversion of 
some petroleum components and pesticides into $\mathrm{CO}_{2}$ and $\mathrm{H}_{2} \mathrm{O}$, and microbial transformation is considered a major route for the complete degradation of petroleum components (Prince 1993). Ongoing studies would allow to follow the temporal and spatial dynamics of the different bacterial communities of the Río de la Plata estuary that were identified as hydrocarbon degrading bacteria. Previous studies already characterized biodegradation of crude oil by marine bacteria in the Bahía Blanca estuary (Cubitto \& Cabezali 1996). Moreover, studies on microbial diversity related to both oil exploration and anoxic conditions are still in progress in the Orinoco Plume. The degree of biodegradation of different substances tested in the Caribbean Colombian sediments seems to be test-specific: in the mixed culture, hydrocarbon degradation was significant (68.61\%) by the action of marine bacteria, as observed in previous studies where the percentage of degradation of the aliphatic fraction between 50 and $91.3 \%$ in a period of three days to a month have been reported (Márquez et al. 2001, Palittapongarnpim et al. 1998, Plohl and Leskovsek 2002, Sharma and Pant 2000). The microbial transformation is recognized as a determining factor that affects the characteristics and conduct of the pesticides in soil and aquatic ecosystems (Cook 1987). Moreover, the effectiveness of remediation agents to treat pesticides and hydrocarbon-polluted sediments may depend on a variety of environmental factors, including oxygen concentration, populations of indigenous bacteria, nutrient concentration and type of contamination (Rojas et al. 1999). We examined the effects of pesticides consortium on the biodegradation of Aldrin by native estuarine bacteria and showed a $20 \%$ reduction in a period 30 days, similar results being reported by El-Bestawy (2000), who found a significant decrease in the rate of degradation and growth of microorganisms with chlorinated compounds in Lake Mariut, Alexandria, Egypt. Finally, the Guanabara Bay study focused in an ecosystem where long-term studies have been conducted since 1997, with a microbial observatory approach (MORio). The principal findings suggest that the inner bay Archaea were related to organisms found in oil, industrial wastes, and sewage, implying that water pollution controls Archaea communities in this system. The detection of a substantial number of uncultured phylotypes suggests that Guanabara Bay harbors a pool of novel Archaeaplankton taxa, that justifies a more detailed study into this diversity (Vieira et al. 2007a). We have also observed a remarkably high Archaeaplankton species diversity at the interface between waste-polluted freshwater and coastal marine waters. On the other hand, Eubacterial communities seem to be rather specific and heterogeneous over abiotic parameters in Guanabara Bay estuarine complex (Vieira et al. 2007b). It is important to address the necessity of performing more studies on microbial diversity in aquatic environments, specifically within tropical coasts, rivers, and lakes, where little is known about biogeography and ecological characteristics of microorganisms. Moreover, microbial diversity patterns and determinism in tropical coastal areas could be better understood by analyzing both water and sediments microbes (where Eubacterial and Archaeal diversity are observed) together with microbes associated with invertebrates (such as sponges).

We presented some of the current directions of the research in the field of marine microbial ecology and diversity in different ecosystems of the Caribbean Sea and tropical, sub-tropical and temperate estuarine and marine areas of South America. This presentation does not intend to be an exhaustive review, as many studies are already published or in progress, as stated in both the South American and Caribbean CoML reviews edited by Gallardo (2003) and Miloslavich and Klein (2005), respectively, in which the status of current and past research in marine biodiversity were described for each of the participant countries. The aim of the LACar-ICoMM network is to facilitae the sharing of common knowledge and capabilities, and to enhance collaboration in order to promote studies on marine microbial ecology and biodiversity in 
the area, by taking into consideration the skills and techniques already available in the different countries of both regions, by making it possible to share the information among the interested scientists of the area and, if possible, by the establishment of common strategies, methodologies and programs. An effort to link different sites of both regions was conducted by a common answer to the "454-tag sequencing” ICoMM worldwide call for proposals to study the metagenomics of the three domains: Archaea, Bacteria and Eukarya. It seems urgent to include microbial diversity assessment by traditional and/or molecular methods, in the already existing or planned local, national, regional and international programs dealing with monitoring of biogeochemical fluxes and patterns in coastal and open ocean systems of both regions, as well as those associated with marine invertebrates (sponges, coral reefs). The link with other CoML and biodiversity programs becomes a priority, as well as capacity building activities that could be organized inside and outside the regions. Finally, we could benefit from the technology and financial support already devoted to the monitoring of some specific threatened ecosystems, in order to conduct the study of microbial diversity of some still existing pristine marine systems near those areas, that could be affected in their structure and functioning by human activities and/or climate change, in the very near future.

\section{AKNOWLEDGMENTS}

We thank ICoMM and the CoML S.S.C. for their support for the launching of the LACar ICoMM initiative, together with both S.A. and Caribbean CoML S.C. chairs, Diego Rodriguez and Patricia Miloslavich, respectively. We also thank the crews of the R.V. employed in the different studies, as well as the National, Regional or International Programs, their chairs, and the directors of the laboratories that supported these studies. We thank the technical and administration staff of our institutes for their help and logistical and financial support, as well as all the colleagues and students involved in these studies. Thanks are due to the three anonymous reviewers for helping us to improve our manuscript.

\section{RESUMEN}

El Censo Internationl de Microbios Marinos (ICoMM), y los comités del Censo de Vida Marina de América del Sur y del Caribe (CoML S.A. y Caribe) apoyaron la iniciativa para el lanzamiento de un nodo regional del ICoMM (LACar ICoMM) para promover la discusión entre investigadores acerca de estudios sobre biodiversidad microbiana en el continente, y permitir el intercambio de información y metodologías, y promover la elaboración de proyectos comunes, para avanzar en el conocimiento de la microbiología marina y su diversidad. En el presente artículo presentamos una reseña acerca de las direcciones de investigación en microbiología marina actualmente en curso en ambas regiones. En lo que concierne a los estudios sobre el fitoplancton, los grupos taxonómicos más estudiados son los de las diatomeas y los dinoflagelados. En las aguas mexicanas el número de táxones descritos llegan a los 1400. Por otra parte, los estudios sobre bacterias y cianobacterias en aguas costeras y oceánicas en diferentes ecosistemas subrayan la importancia de varios tipos de funcionamiento modulados por características geográficas y climáticas estacionales y por la influencia de grandes ríos sudamericanos en la productividad del Mar Caribe. Uno de los principales ejemplos de este tipo de estudios es la determinación del patrón estacional (estación seca y lluviosa) de la dinámica bacteriana en zonas costeras de Puerto Rico, con moderada o ausente influencia continental. La dinámica comparada del fitoplancton y las bacterias es igualmente estudiada en los sistemas costeros y de plataforma continental en la Guayana Francesa, conocida por sus importantes recursos pesqueros y cuyos ecosistemas costeros están bajo influencia directa o indirecta de las aguas y material proveniente del río Amazonas. La biodiversidad microbiana es actualmente estudiada en otros sistemas costeros de interface continental y marina como lo son las lagunas costeras uruguayas (de régimen subtropical). En el Río de la Plata y en aguas adyacentes de la plataforma continental Argentina, se llevan a cabo estudios de la dinámica y diversidad picoplanctónica. Finalmente, se llevan a cabo estudios de las bacterias que abundan en zonas de mínimo de oxígeno mas o menos alejadas de la costa, como es el caso en el Pacífico chileno, al igual que en el golfo de Cariaco en Venezuela, en los cuales se han detectado metabolismos diversos. Por otra parte, se ha buscado determinar patrones de distribución y diversidad de bacterias capaces de degradar hidrocarburos y plaguicidas, como en las costas de Colombia, donde 64 cepas nativas marinas fueron aisladas de sedimentos costeros. Estos últimos estudios se llevan a cabo también en la zona estuarina del Río de la Plata, así como en la zona intermareal patagónica de Argentina. Las bacterias que 
degradan los hidrocarburos son igualmente estudiadas en el delta del Orinoco y plataforma adyacente, sometidos a una fuerte prospección petrolera. Dentro del marco de los estudios de zonas contaminadas, el observatorio microbiológico (MoRio) establecido en la Bahía de Guanabara (Rió de Janeiro, Brasil) constituye un ejemplo y modelo para los ecosistemas marinos tropicales sometidos a una contaminación urbana importante. Compartir conocimiento y metodologías en estrategias comunes, permitirían un mejor conocimiento y comprensión de las pautas de diversidad microbiana en ambas regiones.

Palabras clave: Biodiversidad microbiana, dinámica del fitoplancton y de las bacterias marinas, bioremediación microbiana, América del Sur y Mar Caribe.

\section{REFERENCES}

Abreu, P.C., C. Hartmann \& C. Odebrecht. 1995. Nutrientrich Saltwater and its influence on the phytoplankton of the Patos Lagoon Estuary, Southern Brazil. Estuar. Coast. Shelf Sci. 40: 219-229.

Abreu, P.C., L.C. Ballester, C. Odebrecht, W. Wasielesky Jr., R. O. Cavalli, W. Granéli \& A.M. Anesio. 2007. Importance of biofilm as food source for shrimp (Farfantepenaeus paulensis) evaluated by stable isotopes $\left(\delta^{13} \mathrm{C}\right.$ and $\left.\delta^{15} \mathrm{~N}\right)$. J. Exp. Mar. Biol. Ecol. 347: 88-96.

Aller, R.C., C. Heilbrun, C. Panzeca, Z. Zhu \& F. Baltzer. 2004. Coupling between sedimentary dynamics, early diagenetic processes, and biogeochemical cycling in the Amazon-Guianas mobile mud belt: coastal French Guiana. Mar. Geol. 208: 331-360.

Agard, J.B.R., R.H. Hubbard R.H. \& Griffith J.K. 1996. The relation between productivity, disturbance and the biodiversity of Caribbean phytoplankton: applicability of Huston's dynamic equilibrium model. J. Exp. Mar. Biol. Ecol. 202: 1-7.

Alongi, D.M., 1998. Coastal Ecosystem Processes. In: Marine Sciences Series, CRC Press, Boca Raton, London, New York, Washington D.C. 419 pp.

Anabalón, V., C.E. Morales, R. Escribano \& M.A. Varas. 2007. The contribution of nano- and micro-planktonic assemblages in the surface layer $(0-30 \mathrm{~m})$ under different hydrographic conditions in the upwelling area off Concepción, central Chile. Progr. Oceanogr. 75: 396-414.
Artigas, L.F. 1998. Seasonal variability in microplanktonic biomasses in the Gironde dilution plume (Bay of Biscay) : relative importance of bacteria. Oceanol. Acta 21: 563-580.

Artigas, L.F., A. Herbland \& P. Laborde. 2000. Is the spring bacterioplankton production, on the Aquitanian shelf, a response to primary production? Ozeanografika 3: 185-202.

Artigas, L.F. and D. Guiral. 2002. Seasonal dynamics of microplanktonic biomasses, along a dilution gradient, from the Kaw River to the coastal waters off French Guiana. Proc. VI Workshop ECOLAB, Belém -PA, Brazil, 23-29 September 2002, (CD-ROM).

Artigas, L.F., J.F. Ternon, M. Baklouti, I. Do Rosario Marinho, D. Guiral, M. Thyssen, and B. Beker. 2005. Biogeochmical influence of the Amazon waters on the Guianas shelf: phytoplankton and bacterioplankton short-term variability during a NBC retroflexion period, ASLO Summer meeting, Santiago de Compostela, Spain, June 19-24, 2005.

Artigas, L.F., I. do Rosario Marinho-Jaussaud, J.-F. Ternon, M. Thyssen, M. Baklouti, B. Beker \& D. Guiral. 2007. Bacterioplankton dynamics and ecological role in estuarine, coastal and shelf waters of French Guiana. Proc. VIII Workshop ECOLAB, Macapá, AP, Brazil, August 6-12, 2007: 6-16.

Baklouti, M., J.-L. Devenon, A. Bourret, J.-M. Froidefond, J.-F. Ternon \& J.-L. Fuda 2007. New insights in the French Guiana continental shelf circulation and its relation to the North Brazil Current retroflection. J. Geophys. Res.112, C02023, doi:10.1029/2006JC003520, 2007.

Band-Schmidt, C.J., L. Morquecho, D.U. HernándezBecerril, A. Reyes- Salinas \& E. Bravo-Sierra. 2004. Raphidophyceans on the coasts of Mexico. Hydrobiologia 515: 79-89.

Billen, G., P. Servais \& S. Becquevort. 1990. Dynamics of bacterioplankton in oligotrophic and eutrophic aquatic environments: bottom-up or top-down control? Hydrobiologia 27, 37-42.

Blair, J, M.A. Lever, V.A. Gallardo \& A. Teske. 2007. 16 s ribosomal RNA of the Planktomycetales and Verrucomicrobia in Chilean continental shelf sediments. Gayana 70 (Suppl.1): 93-148. 
Bhadhade, B.J., S.S. Sarnaik \& P.P. Kanekar. 2002. Bioremediation of an industrial effluent containing monocrotophos. Curr. Microbiol. 45: 346-349.

Bonilla, S., V. Hein, D. Conde, N. García \& L. Aubriot. 2004. Phytoplankton and primary productivity: 10 years data. Workshop: Scientific and technical advances for the management of the protected area Laguna de Rocha, Fac. Science, Univ. Montevideo, Uruguay.

Böttjer D. \& C.E. Morales. 2007. Nanoplanktonic assemblages in the upwelling area off Concepción (365), central Chile: Abundance, biomass, and grazing potential during the annual cycle. Prog. Oceanogr. 75: 415-434.

Brandini, F.P., D. Boltovskoy, A. Piola, S. Kocmur, R. Röttgers, P.C. Abreu \& R.M. Lopes. 2000. Multiannual trends in fronts and distribution of nutrients and chlorophyll in the southwestern Atlantic (30-62 $\left.{ }^{\circ} \mathrm{S}\right)$. Deep-Sea Res. I, 47: 1015-1033.

Bravo-Sierra, E. \& D.U. Hernández-Becerril (2003) Parmales (Chrysophyceae) from the Gulf of Tehuantepec, Mexico, including the description of a new species, Tetraparma insecta sp. nov. and a proposal to the taxonomy of the group. J. Phycol. 39: 577-583.

Brito, EM, R. Guyoneaud, M. Goni-Urriza, A. RanchouPeyruse, A. Verbaere, M.A. Crapez, J.C. Wasserman \& Duran. 2006. Characterization of hydrocarbonoclastic bacterial communities from mangrove sediments in Guanabara Bay Brazil. Res. Microbiol. 57: 752-762.

Calliari, D, M. Gomez \& N. Gomez. 2005. Biomass and composition of the phytoplankton in the Río de la Plata estuary: large scale distribution and relationship with environmental variables during a Spring cruise. Continental Shelf Research, 25(2): 197-210.

Capone, D.G., J.A. Burns, J.P. Montoya, A. Subramaniam, C. Mahaffey, T. Gunderson, A.F. Michaels \& E.J. Carpenter. 2005. Nitrogen fixation by Trichodesmium spp: an important source of new nitrogen to the tropical and subtropical North Atlantic Ocean. Global Biogeochem. Cycles 19: doi:10.1029/2004GB002331.

Carpenter, E.J., A. Subramaniam \& D.G. Capone. 2004. Biomass and primary production of the cyanobacterium Trichodesmium spp. in the tropical N. Atlantic ocean. Deep Sea Res. I, 51: 173-203.

Chevaldonné, P. \& A. Godfroy. 1997. Enumeration of microorganisms from deep-sea hydrothermal chimney samples. FEMS Microbiol. Lett. 146: 211-216.
Ciotti, A.M., C. Odebrecht, G. Fillmann \& O. Moller Jr. 1995. Freshwater outflow and Subtropical Convergence influence on phytoplankton biomass on the southern Brazilian continental shelf. Contin. Shelf Res. 15: 1737-1756.

Conde, D., L. Aubriot, \& R. Sommaruga. 2000. Changes in UV penetration associated with marine intrusions and freshwater discharge in a shallow coastal lagoon of the Southern Atlantic Ocean. Mar. Ecol. Prog. Ser. 207: 19-31.

Conde, D., L. Rodríguez-Gallego, G. Lacerot, V. Hein, C. Piccini, E. Meerhoff, G. Cervetto, L. RodríguezGraña, D. Calliari \& S. Masciardi. 2004. Impacto ecológico de la apertura artificial de una laguna costera propuesta como sitio RAMSAR en Uruguay: fundamentos científicos para la gestión de la Laguna de Rocha. Informe Final, Facultad de Ciencias RAMSAR - FPS 2 URY/02 Montevideo.

Constanza, R., W.M. Kemp \& W.R. Boynton. 1993. Predictability, scale and biodiversity in coastal and estuarine ecosystems: implications for management. AMBIO 22: 88-96.

Cook, A.M. 1987. Biodegradation of S-atracine xenobiotics. FEMS Microb. Rev. 46: 93-116.

Corredor, J.E. \& J.M. Morell. 2001. Seasonal variation of physical and biogeochemical features in eastern Caribbean surface waters. J. Geophys. Res. 106: 4517-4525.

Covacevich, F, A. Cumino, R. Silva, R. Negri, K. Valentin, L. Medlinn \& G.L. Salerno. 2006. Determinación de la biodiversidad del picofitoplancton en la plataforma patagónica del Mar Argentino mediante técnicas moleculares. VI Jornadas Nacionales de Ciencias del Mar, Puerto Madryn, Argentina, Diciembre 2006.

Cubitto, M.A. \& C.B. Cabezali. 1996. Biodegradation of crude oil by a marine bacterium isolated from Bahia Blanca Estuary, Argentina. Int. Biodeterio. Biodegrad. 37: 123.

Cuevas, L.A., G. Daneri, B. Jacob \& P. Montero. 2004. Microbial abundance and activity in the seasonal upwelling area off Concepcion $\left(\sim 36^{\circ} \mathrm{S}\right)$, central Cile : a comparison of upwelling and non-upwelling conditions. Deep-Sea Res. II, 51: 2427-2440.

Diaz, RJ. 2001. Overview of hypoxia around the world. J. Environ. Qual. 30: 275-281.

Diez, B., C. Pedrós-Alió, T.L. Marsh \& R. Massana 2001. Application of Denaturing Gradient Gel 
Electrophoresis (DGGE) To Study the Diversity of Marine Picoeukaryotic Assemblages and Comparison of DGGE with Other Molecular Techniques. Appl. Environ. Microbiol. 67: 2942-2951.

El-Bestawy. 2000. Selective bioaccumulation of mixed heavy metals by a range of backrish zater bacteria. Pakistan J. Biol. Sci. 3: 1496-1499.

Everroad, C., C. Six, C., F. Partensky, J.C. Thomas, J. Holtzendorff \& A.M. Wood. 2006. Biochemical bases of type IV chromatic adaptation in marine Synechococcus spp. J. Bacteriol. 188: 3345-3356.

FEEMA. 1990. Projeto de Recuperaçao Gradual do Ecossitema da Baia de Guanabara. Rio de Janeiro. Fundaçao Estadual de Engenheria do Meio Ambiente, 2 vol., 203 p.

Foster, R.A., A. Subramaniam, C. Mahaffey, E.J. Carpenter, D.G. Capone \& J.P. Zehr. 2007. Influence of the Amazon River plume on distributions of free-living and symbiotic cyanobacteria in the western tropical north Atlantic Ocean. Limnol. Oceanorgr. 52: 517-532.

Fuller, N.J., N.J. West, D. Marie, M. Yallop, T. Rivlin, A.F. Post \& D. J. Scanlan. 2005. Dynamics of community structure and phosphate status of picocyanobacterial populations in the Gulf of Aqaba, Red Sea. Limnol. Oceanorgr. 50: 363-375.

Fuhrman, J.A. \& F. Azam. 1982. Thymidine incorporation as a measure of heterotrophic bacterioplankton production in marine surface waters: Evaluation and field results. Mar. Biol. 66: 109-120.

Gallardo, VA. 1977. Large benthic microbial communities in the sulfide biota under the Peru- Chile Subsurface Countercurrent. Nature 268: 331-332.

Gallardo, V.A. (Ed.). 2003. First South American Workshop on Marine Biodiversity. Gayana 67: 139-382.

Gallardo, V.A. \& C. Espinoza. 2007. New communities of large filamentous sulfur bacteria in the eastern South Pacific. Int. Microbiol.10: 97-102.

Gómez, M.L., C. Hurtado, J. Dussan, J.P. Parra \& S. Narváez. 2006. Determinación de la capacidad degradación de compuestos orgánicos persistentes por bacterias marinas aisladas de sedimentos del Caribe colombiano. Actual. Biol. 28: 125-137.

González, H. E., E. Menschel, C. Aparicio \& C. Barría. 2007. Spatial and temporal variability of microplankton and detritus, and their export to the shelf sediments in the upwelling area off Concepción, Chile (36º $)$, during 2002-2005. Prog. Oceanogr. 75: 435-451.

Goosen, N.K., J. Kromkamp, J. Peene, P. Van Rijswijk \& P. Van Bruegel. 1999. Bacterial and phytoplankton production in the maximum turbidity zone of three European estuaries: the Elbe, Weterschelde and Gironde. J. Mar. Syst. 22: 151-171.

Graco, M., L. Farías, V. Molina, D. Gutiérrez \& L.P. Nielsen. 2007. Massive developments of microbial mats following phytoplankton blooms in a naturally eutrophic bay: Implications for nitrogen cycling. Limnol. Oceanogr. 46: 821-832.

Grob, C., O. Ulloa, W.K.W. Li, G. Alarcón, M. Fukasawa \& S. Watanabe (2007). Picoplankton abundance and biomass across the eastern South Pacific Ocean along 32.5º. Mar. Ecol. Prog. Ser. 332: 53-62.

Hamersley, M. R., G. Lavik, D. Woebken, J.E. Rattray, P. Lam, E.C. Hopmans, J.J.S.S. Dampsté, S., Krüger, M. Graco, D. Gutiérrez \& M.M.M. Kuypers. 2007. Anaerobic ammonium oxidation in the Peruvian oxygen minimum zone. Limnol. Oceanogr. 52: 923-933.

Helly, JJ \& L. Levin. 2004. Global distribution of cas naturally occurring marine hypoxia on continental margins. Deep-Sea Res. I, 51:1159-1168.

Hernández, K.L., R. A. Quiñones, G. Daneri, M. E. Farias \& E. W. Helbling. 2007. Solar UV radiation modulates daily production and DNA damage of marine bacterioplankton from a productive upwelling zone (365), Chile. J. Exp. Mar. Biol. Ecol. 343: 82-95.

Hernández-Becerril, D.U. \& E. Bravo-Sierra. 2001. Planktonic silicoflagellates (Dictyochophyceae) from the Mexican Pacific. Bot. Mar. 44: 417-423.

Hernández-Becerril, D.U., E. Bravo-Sierra \& Y. RamírezValdéz. 2001. Coccolithophorids from the west coast of Baja California, Mexico. Hydrobiologia 452: 31-45.

Hernández-Becerril, D.U. 2003. La diversidad del fitoplancton marino de México: un acercamiento actual. pp. 1-17. En: Barreiro, M.T., Meave, M.E., Signoret, M. \& Figueroa, M.G. (Eds.). Planctología Mexicana. Sociedad Mexicana de Planctología (SOMPAC) y Universidad Autónoma Metropolitana. México DF.

Hernández-Becerril, D.U. \& E. Bravo-Sierra. 2004. New records on planktonic dinoflagellates (Dinophyceae) from the Mexican Pacific Ocean. Bot. Mar. 47: 417-423. 
Herrera, L. \& R. Escribano. 2006. Factors structuring the phytoplankton community in the upwelling site off El Loa River in northern Chile. J. Mar. Syst. 61: 13-38.

Hewson, I. \& J.A. Fuhrman. 2007. Covariation of viral parameters with bacterial assemblage richness and diversity in the water column and sediments. DeepSea Res. I, 54: 811-830.

Hubas, C., D. Lamy, L.F. Artigas, D. Davoult. 2007. Seasonal variability of intertidal bacterial metabolism and growth efficiency in an exposed sandy beach during low tide. Mar. Biol. 151:41-52

Iriarte, J.L., H.E. González, K.K. Liu, C. Rivas \& C. Valenzuela. 2007. Spatial and temporal variability of chlorophyll and primary productivity in surface waters of southern Chile (41.5-43으). Estuar. Coast. Shelf Sci. 74: 471-480.

Jilani, S. \& M.A. Khan. 2004. Isolation, characterization and growth response of pesticidas degrading bacteria. J. Biol. Sci. 4: 15-20.

Jorcin, A. 1999. Temporal and spatial variability in the macrobenthic community along a salinity gradient in the Castillos lagoon (Uruguay). Arch. Hydrobiol. 146: 369-384.

Kepner, Jr, R.L. \& J.R. Pratt. 1994. Use of fluorochromes for direct enumeration of total bacteria in environmental samples: past and present. Microbiol. Mol. Biol. Rev. 58: 603-615.

Kjerfve, B.J. 1994. Coastal Lagoons: Pp. 1- 8. In: B.J. Kjerfve (ed.). Coastal Lagoon Processes. Elsevier, Amsterdam, Netherlands.

Kirchman, D.L. 1993. Leucine incroporation as a measure of biomass production by heterotrophic bacteria: Pp. 509-512. In: P.F. Kemp, B.F. Sherr, E.B. Sherr \& J.J. Cole (Eds.). Handbook of Methods in Aquatic Microbial Ecology. Lewis, Boca Raton, Florida, USA.

Lamy, D., L.F Artigas, C. Jauzein, F. Lizon \& V. Cornille. 2006. Coastal bacterial viability and production in the eastern English Channel: A case study during a Phaeocystis globosa bloom. J. Sea Res. 56: 227-238.

Levipan, H.A., R.A. Quiñones \& H. Urrutia. 2007. A time series of prokaryote secondary production in the oxygen minimum zone of the Humboldt current system, off central Chile. Prog. Oceanogr. 75: 531-549.

Licursi, M., M.V. Sierra \& N. Gomez. 2006. Diatom assemblages from a turbid coastal plain estuary; Rio de la Plata (South America). J. Mar. Syst. 62: 35-45.

Limburg, K.E. \& C. Folke. 1999. The ecology of ecosystem services: introduction to the special issue. Ecol. Econ. 29: 179-182.

Madrid, V.M., J.Y. Aller, R.C. Aller \& A.Y. Chistoserdov. 2001. High prokaryote diversity and analysis of community structure in mobile mud deposits off French Guiana: identification of two new bacterial candidate divisions. FEMS Microb. Ecol. 37: 197-209.

Malavé, R., M. Barbosa \& P. Suárez. 2005. Detección de bacterias tolerantes a metales en el agua y los sedimentos del Frente Atlántico Venezolano. En: Frente Atlántico Venezolano. Tomo I. Ciencias Ambientales. Coordinación. Rubén Figuera. Compilación: María Gabriela Gómez, Mario Capaldo, Carlos Yanes y Alberto Martín. Fondo Editorial Fundambiente, Caracas, Venezuela: 22-30.

Margalef, R. 1972. Regularidades en la distribucion de la diversidad del fitoplancton en un area del mar Caribe. Inv. Pesq. 33: 241-264.

Margalef, R. \& F. González-Bernáldez F. 1969. Grupos de especies asociadas en el fitoplancton del mar Caribe (NE de Venezuela). Inv. Pesq. 33: 287-312.

Marin, B., J. Garay, G. Ramirez, J. Betancourt, W. Troncoso, M. Gomez, J. Sanchez, B. Cadavid, J. Acosta, J. Vivas, M. Casas, P. Lozano \& L. Arias. 2004. Diagnostico y evaluacion de la calidad ambiental marina en el Caribe y Pacifico colombiano. Red de vigilancia para la conservacion y proteccion de las aguas marinas y costeras de Colombia. Diagnostico Nacional y Regional. INVEMAR. Santa Marta.

Marquez, F., V. Hernández \& T. Lamela. 2001. Biodegradation of diesel oil in soil by a microbial consortium. Water Air Soil Poll. 128: 313-320.

Martínez, A. \& L. Ortega. 2007. Seasonal trends in phytoplankton biomass over the Uruguayan Shelf. Contin. Shelf Res. 27: 1747-1758.

Mayr, L.M., D.R. Tenenbaun, M.C. Villac, R. Paranhos, C.R. Nogueira, S.L.C. Bonecker \& A.C. Bonecker. 1989. Hydrobiological characterization of Guanabara Bay coastlines of Brazil. Amer. Soc. Civil Engin. 1:124-139.

Meniconi, M.D.G., I.T. Gabardo, M.E.R. Carneiro et al. 2002. Brazilian oil spills chemical characterization. Environ. Foren. 3: 303-321. 
Miloslavich, P. \& E. Klein. (Eds.) 2005. Caribbean Marine Biodiversity : the Known and the Unknown. Universidad Simón Bolívar, DEStech, Lankaster, Pennsylvania.

Morales, C.E., H.E. González, S.E. Hormazábal, G. Yuras, J. Letelier \& L.R. Castro. 2007. The distribution of chlorophyll-a and dominant planktonic components in the coastal transition zone off Concepción, central Chile, during different oceanographic conditions. Progr. Oceanogr. 75: 452-469.

Muller-Karger, F., R. Varela, R. Thunell, Y. Astor, H. Zhang, R. Luerssen and C. Hu. 2004. Processes of coastal upwelling and carbon flux in the Cariaco Basin. Deep Sea Res. II, 51: 927-943.

Okolodkov, Y.B. 2005. Protoperidinium Bergh (Dinoflagellata) in the southeastern Mexican Pacific Ocean: part I. Bot. Mar. 48: 284-296.

Palittapongarnpim, M., L. Pokethitiyook, E. Suchart \& M. Tangbanluekal. 1998. Biodegradation of crude oil by soil microorganisms in the tropic. Biodegradation 9: 83-90.

Paulmier, G. 1993. Microplancton des eaux marines et saumâtres de la Guyane et des Antilles françaises. Editions de l'ORSTOM, Institut français de recherche scientifique pour le développement en coopération, collection études et thèses, Paris. 436 p.

Pernthaler, A., J. Pernthaler \& R. Amann. 2004. Sensitive multicolour fluorescence in situ hybridization for the identification of environmental organisms, p. 711-726. In G.A. Kowalchuk, F.J. De Bruijn, I.M. Head, A.D.L. Akkermans \& J.D. van Elsas (eds.). Molecular Microbial Ecology Manual, 2nd ed. Kluwer, Dordrecht, Netherlands.

Plohl, K. \& H. Leskovsek. 2002. Biological degradation of motor oil water. Acta Chim. Slovenica 49 : 279-289.

Piccini, C., D. Conde, C. Alonso, R. Sommaruga \& J. Pernthaler. 2006. Blooms of single bacterial species in a coastal lagoon of the Southwestern Atlantic Ocean. Appl. Environ. Microbiol. 72: 6560-6568.

Porter, K.G. \& Y.S. Feig. 1980. The use of DAPI for identifying and counting aquatic microflora. Limnol. Oceanogr. 25: 943-948.

Prince, R.C. 1993. Petroleum spill bioremediationin marine environments. Crit. Rev. Microbiol. 19 : 217-242.

Rivera P. \& L. Herrera. 2000. First record of Neostreptotheca torta von Stosch F. triangularis von
Stosch (Bacillariophyceae) from the southeastern Pacific. Cryptog. Algol. 21: 73-78.

Rocap, G., D.L. Distel, J.B. Waterbury \& S.W. Chisholm. 2002. Resolution of Prochlorococcus and Synechococcus ecotypes by using 16S-23S ribosomal DNA internal transcribed spacer sequences. Appl. Environ. Microbiol. 68: 1180-1191.

Rojas, A., R. Rodriguez-Vazquez, F. Enriquez-Villanueva, J. Martinez-Cruz \& H. Poggi-Varaldp. 1999. Transformer oil degradation by an indigenous microflora isolated from a contaminated soil. Resour. Conserv. Recycl. 27: 15-26.

Sambrook, J. \& D.W. Russell. 2001. Molecular Cloning. A Laboratory Manual, 3rd. ed. Cold Spring Harbor Lab., New York.

Sharma, S. \& A. Pant. 2000. Biodegradation and conversion of alkanes and crude oil by marine Rhodococcus sp. Biodegradation 11: 289-294.

Shipe, R.F., J. Curtaz, A. Subramaniam, E.J. Carpenter \& D.G. Capone. 2006. Diatom biomass and productivity in oceanic and plume-influenced waters of the western tropical Atlantic ocean. Deep-Sea Res. I, 53: 1320-1334.

Somerville, C.C., I.T. Knight, W.L. Straube \& R.R. Colwell. 1989. Simple rapid method for direct isolation of nucleic acids from aquatic environments. Appl. Environ. Microbiol. 55: 548-554.

Stoeck, T., B. Hayward, G.T. Taylor, R. Varela \& S.S. Epstein. 2006. A Multiple PCR-primer approach to access the microeukaryotic diversity in environmental samples. Protist 157: 31-43

Sylvestre, F., D. Guiral \& J.P. Debenay. 2004. Modern diatom distribution in mangrove swamps from the Kaw estuary (French Guiana). Mar. Geol. 208: 281-293.

Ternon, J.F., M. Baklouti, D. Guiral, L.F. Artigas, I. Do Rosario Marinho \& B. Beker. 2005. Functioning of coastal pelagic ecosystems in French Guiana: Influence of remote (Amazone plume) and local factors, TOS 2005 International Ocean Research Conference, UNESCO, Paris, June 6-10, 2005.

Thyssen, M., D. Lefèvre, G. Caniaux, J. Ras, C.I. Fernández \& M. Denis. 2005. Spatial and distribution of heterotrophic bacteria in the northeast Atlantic (POMME study area) during spring 2001. J. Geophys. Res. 110: C07S16. 
Utermöhl, M. 1958. Über das umgekehehrte Mikroskop. Arch. Hydrobiol. Beih. Ergebn. Plankt. 22: 643-645.

Vieira, R.P., M. Clementino, A.M. Cardoso, D.N. Oliveira, R.M. Albano, A.M. Gonzalez, R. Paranhos \& O.B. Martins. 2007a. Archaeal communities in a tropical estuarine ecosystem: Guanabara Bay, Brazil. Microb. Ecol., in press, DOI: 10.1007/s00248- 007-9261-y.

Vieira, R.P., A.M. Gonzalez, A.M. Cardoso, D.N. Oliveira, R.M. Albano, M. Clementino, O.B. Martins \& R. Paranhos. 2007b. Bacterioplankton assemblages across a trophic and pollution gradient in a tropical bay: Rio de Janeiro, Brazil. Environ. Microbiol., in press, DOI.10.1111/j.1462-2920.207.01443.x.

\section{INTERNET REFERENCES}

Otero, E. 2001. Bacterial abundance and production in contrasting coastal systems of southwestern, Puerto Rico. ASLO Aquatic Sciences Meeting February 12-16, 2001, Albuquerque, NM. http://aslo.org/albuquerque2001/1023.html 